\title{
Pharmacological and computational evaluation of fig for therapeutic potential in hyperactive gastrointestinal disorders
}

\author{
Muhammad Bilal Riaz, Arif-ullah Khan ${ }^{*}$ and Neelam Gul Qazi
}

\begin{abstract}
Background: Ficus palmata (Fig), are distributed in different parts of the world, and are used in traditional medicine to treat various ailments including inflammation, tumor, epilepsy, jaundice, influenza and bacillary dysentery. The present study aimed to evaluate the antidiarrheal, antisecretary, antispasmodic, antiulcer and anti motility properties of Ficus palmata.
\end{abstract}

Methods: In-vivo, in-vitro and in-silico techniques were used to investigate various gastrointestinal effects of Ficus palmata. Antidiarrheal, antisecretary, antispasmodic, antiulcer, anti motility and molecular docking were performed using castor oil induced diarrhea and fluid accumulation, isolated tissue preparations, ethanol-HCl induced ulcer assay, charcoal meal transit time and Auto Doc Vina.

Results: Ficus palmata crude extract ( $F p . C r$ ) exhibited protection against castor oil-induced diarrhea in mice and dose-dependently inhibited intestinal fluid secretions. Fp.Cr caused relaxation of spontaneous and $\mathrm{K}^{+}$ $(80 \mathrm{Mm})$-induced contractions in isolated rabbit jejunum preparations. It showed protective effect against gastric ulcers induced by ethanol-hydrochloric acid in rats. Fp.Cr reduced distance travelled by charcoal meal in the gastrointestinal transit model in mice. The plant constituents: psoralenoside and bergapten showed high binding affinities (E-value $\geq-6.5 \mathrm{Kcal} / \mathrm{mol}$ ) against histaminergic $\mathrm{H}_{1}$, calmodulin and voltage gated $\mathrm{L}$ type calcium channels, while showed moderate affinities (E-value $\geq 7 \mathrm{Kcal} / \mathrm{mol}$ ) against dopaminergic $\mathrm{D}_{2}$, adrenergic $a_{1}$, muscranic $M_{3}$, mu-opioid, whereas revealed lower affinities (E-value $\geq 9.5 \mathrm{Kcal} / \mathrm{mol}$ ) vs. muscranic $\mathrm{M}_{1}$, histaminergic $\mathrm{H}_{2}$ and $\mathrm{H}^{+} / \mathrm{K}^{+}$ATPase pump. Germanicol acetate and psoralene exhibited weak affinities against aforementioned targets.

Conclusion: This study reveals that Ficus palmata possesses anti-diarrheal, anti-secretory, anti-spasmodic, anti-motility and anti-ulcer activities. The various constituents reveal different binding affinities against target proteins, which mediate the gastrointestinal functions.

Keywords: Ficus palmata, Anti-diarrheal, Anti-secretory, Anti-spasmodic, Anti-ulcer, Molecular docking

\section{Background}

High prevalence of gastrointestinal disorders among Asian population has caused significant suffering and it is generally considered by the health care professionals to be a leading cause for the incidence of a number of other concomitant disease conditions. Evidence based medicine has not yet succeeded in introducing any sufficiently safe and efficacious drug for

\footnotetext{
* Correspondence: arif.ullah@riphah.edu.pk; arifullahkhan979@hotmail.com Riphah Institute of Pharmaceutical Sciences, Riphah International University, Islamabad, Pakistan
}

the cure of gastrointestinal ailments. Most of the available remedies provide only short-term relief accompanied by various undesirable effects. Nevertheless, conventional phytotherapies have proved to be more cost-effective and long-lasting in the treatment of gastric problems [1]. These herbal products have emerged as a remarkable source to contribute to the discovery of a number of lead compounds and contemporary marketed medicines. Around $61 \%$ of the total drugs launched globally have been extracted from naturally originated herbal products [2]. 
In-vivo evaluation of crude plant extracts aids to screen out newer bioactive lead molecules and their further processing for structural exploration can lead to the development of novel therapies. For obtaining desirable therapeutic effects, pure form of bioactive constituents can be formulated into appropriate dosage forms as well as doses and dosing frequency can be decided [3]. Many chronic disorders have been successfully cured by phytotherapies particularly by edible fruits being consumed as functional foods as well as their active constituents. Several previous studies have demonstrated the potential of crude extracts of a number of edible fruits to treat the gastrointestinal tract diseases [4].

Ficus palmata commonly known as 'Fig' and locally "Injeer" belongs to the family Moraceae that consists of about 800 species [5]. It is found in the Himalayan region, so also named as Wild Himalayan Fig and is mainly the native of Northern areas of Pakistan. Majority of the members of the family are very tall trees, shrubs and sporadically herbs often with milky juice [6]. Variety of Ficus species are used in folk medicine as anti-inflammatory, anti-tumor and tonic medicament [7]. Diseases such as epilepsy, jaundice, influenza, whooping cough, tonsillitis, bronchitis, enteritis, bacillary dysentery, toothache and bruises are also reported to be cured by Ficus extracts. Antioxidant activity was exhibited by Ficus palmata [8]. Various pharmacological activities such as nephroprotective, hepatoprotective and anticoagulant activities are also possessed by this plant [9].

The chemical analysis on genus Ficus, reveals the presence of sterols, terpenes, isoflavones, lignans, glycosides [10], coumarins, furanocoumarin and chromone [11]. Phytochemical investigation of the aerial parts of Ficus palmata resulted in the isolation of 6 compounds; germanicol acetate, psoralene, bergapten, vanillic acid, psoralenoside and flavone glycoside rutin [10].

In the present study, we report anti-diarrheal, antisecretary, anti-spasmodic, anti-motility and anti-ulcer effects. Aforementioned ethnomedicinal uses of the plant were validated by using baseline data from traditional uses and previous studies. Molecular docking of its constituents with known structure is done to find out the potential lead molecule responsible for pharmacological effects.

\section{Methods}

\section{Plant material and extraction}

Superior quality of Ficus palmata fruit weighing $2 \mathrm{~kg}$ were purchased from local market in Feb 2017. Plant was authenticated by a taxonmist Dr. Mushtaq Ahmad, at Department of Plant Sciences, Quaid-i-
Azam University, Islamabad. Voucher specimen no. (ISL-B-24) was collected after submitting sample of specimen of these species to the herbarium at same department. The fruit $(2 \mathrm{~kg})$ was air-dried, crushed into powdered form and extracted at room temperature with aqueous-methanol (70:30) three times to obtain Ficus plmata crude extract (Fp.Cr).

\section{Chemicals}

Atropine sulphate, omeprazole, verapamil, loperamide, acetylcholine, charcoal, methanol and ethanol (Sigma Chemicals Co, St Louis, MO, USA) were used. Castor oil was obtained from KCL Pharma, Karachi, Pakistan.

\section{Animals}

Sprague-Dawley rats (180-220 g), Balb/C mice (25-30 g) and rabbits $(1.0-1.2 \mathrm{~kg})$, of either sex were obtained from animal house of the Riphah Institute of Pharmaceutical Sciences (RIPS) Islamabad. The animals were kept in $595 \times 380 \times 200 \mathrm{~mm}$ plastic cages at standard temperature $\left(23-25^{\circ} \mathrm{C}\right)$ and a $12: 12$ light: dark cycle with lights on at 08:00 and off at 20:00. They were fed with standard animal feed and tap water ad libitum. Animals were fasted before each experiment for $24 \mathrm{~h}$. During housing, animals were monitored twice daily for health status. No adverse events were observed. All the animal experimental protocols were approved by Research and Ethics Committee of RIPS (Ref. no. REC/RIPS/2017/008) which were performed in accordance with the guidelines of "Principles of Laboratory Animal care" [12]. All sections of this report adhere to the Animal Research:Reported of In-vivo Experiments (ARRIVE) Guidelines for reporting animal research. A completed ARRIVE guidelines checklist is included in Checklist S1.

\section{Castor oil-induced diarrhea}

This method was previously reported by Umer et al. [13]. All the test animals were fasted for $24 \mathrm{~h}$ prior to commencement of experimentation and were divided in five groups $(n=5)$. The floor of cage was lined with blotting paper in which animals were placed. First group was assigned as negative control group and received normal saline $(10 \mathrm{~mL} / \mathrm{kg})$ orally, while second group was given with a dose of loperamide hydrochloride $(10 \mathrm{mg} / \mathrm{kg}$, p.o.), assigned as positive control. Third, fourth and fifth groups received 50, 100 and $300 \mathrm{mg} / \mathrm{kg}$ body weight of the extract orally respectively. After one hour of administration of the respective doses and treatments, all animals received castor oil $(10 \mathrm{~mL} / \mathrm{kg}$, p.o.). Post treatment evaluation was carried out after waiting $4 \mathrm{~h}$ in order to analyze 
the diarrheal droppings presence, absence of diarrheal droppings was documented as a positive result.

\section{Assessment of intestinal fluid accumulation}

This method was previously described by Teke et al. [14]. To study the intestinal fluid accumulation, enteropooling assay was used. Overnight fasted mice were taken and put into five assigned cages with five mice in each. Group I and II were administered with normal saline $(10 \mathrm{~mL} / \mathrm{kg})$ and castor oil $(10 \mathrm{~mL} / \mathrm{kg}$, p.o.) respectively. Extract doses of 50,100 and $300 \mathrm{mg} / \mathrm{kg}$ intraperitoneally were given to Group III, IV and V respectively.

Standard drug atropine at dose $10 \mathrm{mg} / \mathrm{kg}$ was given to last group, $1 \mathrm{~h}$ prior induction with castor oil $(10 \mathrm{~mL} / \mathrm{kg}$, p.o.). Mice were sacrificed by cervical dislocation after $30 \mathrm{~min}$, then intestine was removed and weighed. The results were calculated as: $(\mathrm{Pi} / \mathrm{Pm}) \times 1000$ where $\mathrm{Pi}$ is the weight $(\mathrm{g})$ of the intestine and $\mathrm{Pm}$ is the weight of the animal. Later the dead animals were disposed off by burial method.

\section{Isolated tissue preparation}

Before experiment rabbits were fasted for $24 \mathrm{~h}$. Jejunal portion was isolated after cervical dislocation of rabbit and washed with Tyrode's solution. In tissue organ bath containing Tyrode's solution $2 \mathrm{~cm}$ of jejunal segment was suspended. Temperature of bath was kept at $\left(37^{\circ} \mathrm{C}\right)$ and proper aeration of $95 \% \mathrm{O}_{2}$ and $5 \% \mathrm{CO}_{2}$ (carbogen) is ensured. $1 \mathrm{~g}$ initial load was applied to tissue and allowed to equilibrate for $30 \mathrm{~min}$ before the addition of any drug. Following equilibration period, each preparation was then stabilized with sub-maximal concentration of ACh $(0.3 \mu \mathrm{M})$ at 3 min interval until constant responses were recorded via a force displacement transducer (model FT-03) coupled with bridge 7 amplifier and power Lab 4/25 data acquisition system connected to computer running Lab-Chart 6 software (AD Instrument, Sydney Australia). The \% change in the voluntary contractions of jejunum were recorded for $\mathrm{Fp} . \mathrm{Cr}(0.01-$ $3 \mathrm{mg} / \mathrm{mL}$ ) [15]. Later the dead animals were disposed off by burial method.

\section{Ethanol- $\mathrm{HCl}$ induced ulcer assay}

Rats weighing $250-280 \mathrm{~g}$ of either sex were distributed in 5 groups $(n=5)$. Group 1 served as a negative control received normal saline $10 \mathrm{~mL} / \mathrm{kg}$ body weight, group 2 received $20 \mathrm{mg} / \mathrm{kg}$, (p.o.) omeprazole as standard drug, group 3, 4 and 5 received 50, 100 and $300 \mathrm{mg} / \mathrm{kg}$, (p.o.) of Fp.Cr respectively. All the animals were treated with $1 \mathrm{~mL} / 100 \mathrm{~g}$ of ethanol- $\mathrm{HCl}$ mixture (p.o.) i.e. (0.3 M Hydrochloric acid and ethanol 60\%) after $1 \mathrm{~h}$ to induce gastric ulcer. Animals were sacrificed via cervical dislocation one hour after administration of ethanol- $\mathrm{HCl}$ mixture. The stomach were removed and lesion index was estimated by measuring each lesion in $\mathrm{mm}$ along its greater curvature. Each lesion surface area was measured and scoring was done as described previously by [16]. For each stomach lesion, ulcer index was taken as mean ulcer score (US). For each stomach injury sum of the lengths $(\mathrm{mm})$ of all sores was utilized as the ulcer index (UI). The gastro protective assessment was displayed as an inhibition percentage (I \%) calculated by the following formula:

$\mathrm{I}(\%)=(\mathrm{USc}-$ USt $) 100 /$ USc.

Where USc $=$ ulcer surface area of control and USt $=$ ulcer surface area of test drug group.

Later the dead animals were disposed off by burial method.

\section{Charcoal meal transit time}

Gastrointestinal transit time was estimated utilizing the charcoal meal test [17]. Rats were fasted for $24 \mathrm{~h}$, the test groups received the extract at 50,100 and $300 \mathrm{mg} /$ $\mathrm{kg}$ body weight doses, where as positive control group received atropine sulfate $(0.1 \mathrm{mg} / \mathrm{kg}$, i.p. $)$, while the negative control group received normal saline $(10 \mathrm{~mL} / \mathrm{kg}$, p.o.). 30 mins after all treatments, all the animals were sacrificed by cervical dislocation. The small intestine was excised after which the distance travelled by charcoal meal through the organ was expressed as a percentage of the length of the small intestine according to the following expression.

Intestinal transit $(\%)=($ Distance moved by charcoal meal/ total length of intestine) $(\mathrm{cm}) \times 100$.

Later the dead animals were disposed off by burial method.

\section{Computational studies}

3-D structures of the test compounds bergapten, psoralene, psoralenosid and germanicol acetate were constructed by using the software of Gauss View 5.0. 3 dimensional structures of reference drugs were prepared through Discovery Studio Visualizer (2016) as shown in Fig. 1. Through same software, polar hydrogen atoms (H-atoms) were added in it and then saved as PDB file. Reference drugs included phenoxy benzamine, verapamil, calmozoilum, domperidone, ranitidine, piranzapine, atropine, loperamide, omeprazole and pyrilimiine. 3-D structures of selected targets possibly involved in the gut physiology, were retrieved from the website of RCSB protein data bank as represented in Fig. 2. Selected targets included adrenergic $\alpha_{1}$ receptor (PDB ID: 3538), muscranic $M_{1}$ (PDB ID: 5CXV), muscranic $M_{3}$ (PDB 9 ID: 4 U14), dopaminergic $\mathrm{D}_{2}$ (PDB ID: 6CM4), calmodulin (PDB ID: 1CTR), mu-opioid (PDB ID: 5CM), voltage gated L-Type calcium channel (PDB ID: 1T3S), histaminergic $\mathrm{H}_{1}$ (PDB ID: 3RZE), histaminergic $\mathrm{H}_{2}$ 

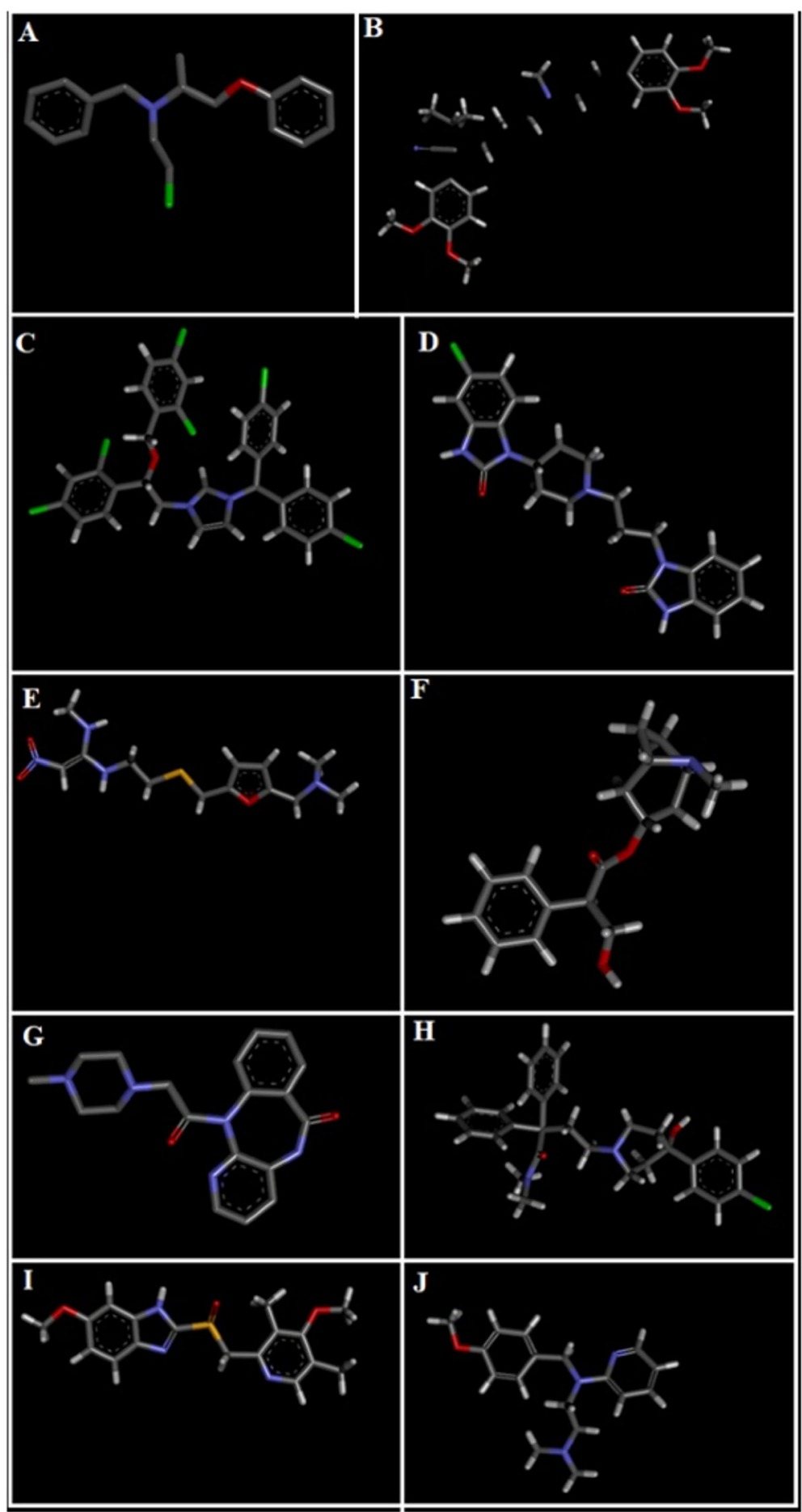

Fig. 1 3D-structures of reference drugs: a phenoxy benzamine, $\mathbf{b}$ verapamil, c calmozolium, $\mathbf{d}$ domperidone, e ranitidine, $\mathbf{f}$ piranzapine, $\mathbf{g}$ atropine, $\mathbf{h}$ loperamide, $\mathbf{i}$ omeprazole and (j) pyrilimine, drawn through Chem Sketch 2015, 2.5 and saved in PDB format through Biovia Discovery Studio 2016. Atoms are shown by colors; gray color (carbon atoms), white color (hydrogen atoms), red color (oxygen atoms), blue color (nitrogen atoms), dark red (bromine), and yellow color (sulfur atoms)

(PDB ID: P25021) and $\mathrm{H}^{+} / \mathrm{K}^{+}$ATPase (PDB ID: 5YLU). Water molecules and ligands were removed along with addition of polar $\mathrm{H}$-atoms by using same software and then saved in PDB format. Autodock Vina which is a geometry based automatic docking tool is used through which molecular docking was performed. A definite 


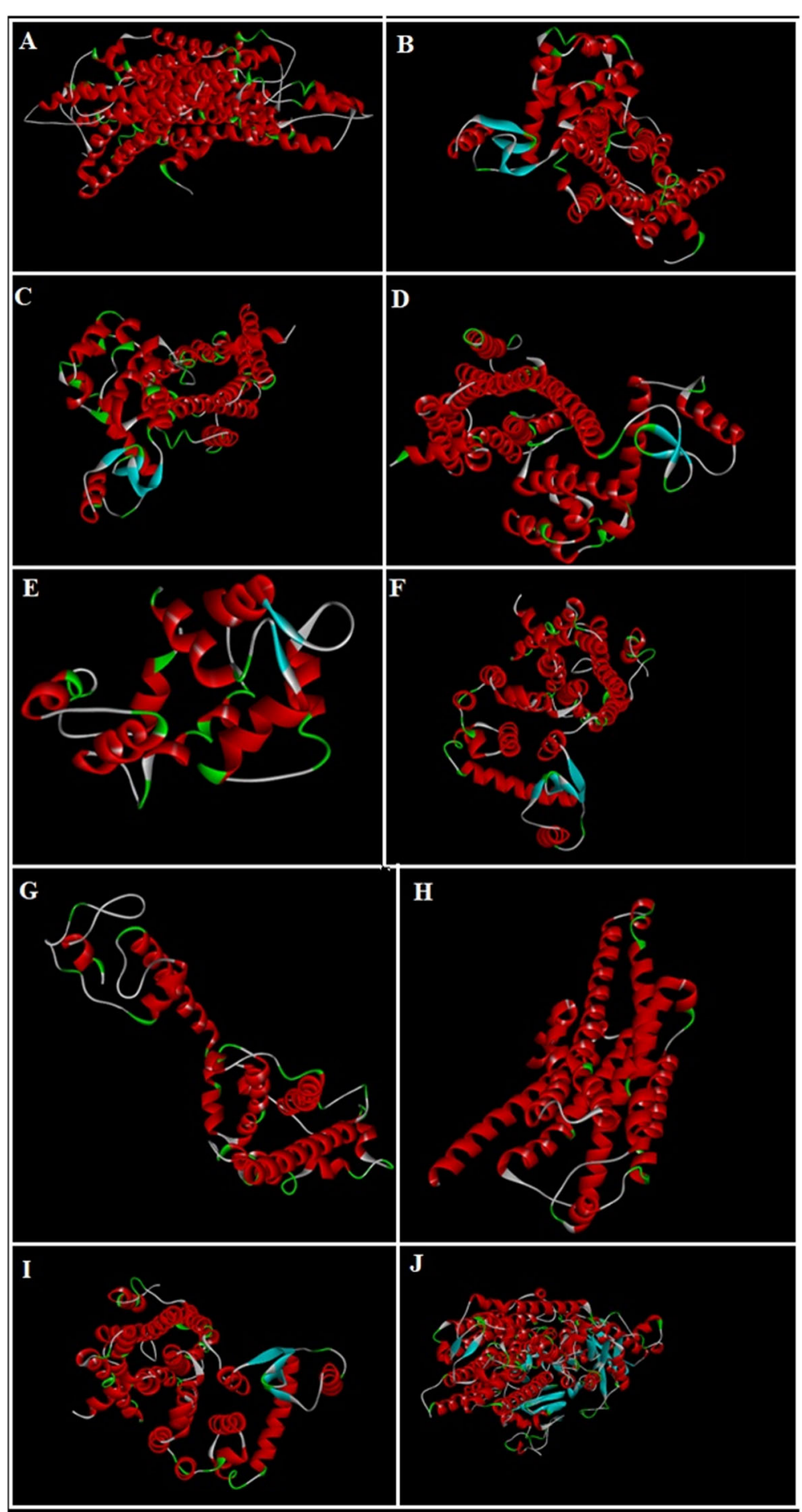

Fig. 2 3D-structures of protein targets: a adrenergic $a_{1}$ receptor, $\mathbf{b}$ muscranic $M_{1}, \mathbf{c}$ muscranic $M_{3}$, d dopaminergic $D_{2}$, e calmodulin, $\mathbf{f}$ mu-opioid, $\mathbf{g}$ voltage gated L-Type calcium channel, $\mathbf{h}$ histaminergic $\mathrm{H}_{1}$, i histaminergic $\mathrm{H}_{2}$, and (j) $\mathrm{H}^{+} / \mathrm{K}^{+}$ATPase pump

value of Root Mean Square of deviation clustering 2 was taken as criteria for elimination of irrelevant findings. Evaluation of docking result was based on atomic energy in $\mathrm{Kcal} / \mathrm{mol}$ [18]. Assessment of top twenty conformations was performed and only one pose having lowest value of atomic energy in $\mathrm{Kcal} / \mathrm{mol}$ was further processed for post dock analysis through Discovery Studio Visulizer 2016. Assessment in 2-D design was made to check the most extreme restricting interactions of complex framed amongst amino acid residues and ligands 
including: valine (VAL), alanine (ALA), proline (PRO), arginine (ARG), threonine (THR), lysine (LYS), proline (PRO), glycine (GLY), glutamine (GLN), asparagine (ASN), cysteine (CYS), methionine (MET), glutamic acid (GLU), histidine (HIS), phenylalanine (PHE), isoleucine (ILE), tyrosine (TYR), serine (SER), threonine (THR), aspartic acid (ASP) and tryptophan (TRP).

\section{Statistical analysis}

Data was expressed as Mean $\pm \operatorname{SEM} \quad(n=5)$ and median effective concentrations (EC50) having 95\% confidence intervals. Statistical analysis of the results was analyzed using one-way ANOVA followed by post-hoc Tukey's test. Chi square test was used in the case of the antidiarrheal data, where $p<0.05$ was regarded as significant. Non-linear regression using Graph 10 Pad program (GraphPAD, SanDiego, CAUSA) was used to analyze the concentration-response curves.

\section{Result}

\section{Effect on castor-oil induced diarrhea}

Fp.Cr showed a dose-dependent $(50-300 \mathrm{mg} / \mathrm{kg})$ protective effect. The saline treated group (negative control) did not show any protection against castor oil-induced diarrhea. Fp.Cr, exhibited 20, 60 and $80 \%$ protection from diarrhea at 50,100 and $300 \mathrm{mg} / \mathrm{kg}(p<0.05$ vs. saline group). Positive control group, loperamide (10 mg/ $\mathrm{kg}$ ) showed $100 \%$ protection ( $p<0.01$ vs. saline group) (Table 1).

\section{Effect on intestinal fluid accumulation}

When tested against castor oil-induced intestinal fluid accumulation in mice, Fp.Cr exhibited a dosedependent $(50-300 \mathrm{mg} / \mathrm{kg})$ anti-secretory effect. In the saline treated group intestinal fluid accumulation was $81.9 \pm 0.84 \quad($ mean \pm SEM, $n=5)$, castor oil-treated group showed $122.5 \pm 0.55$ ( $p<0.001$ vs. saline group). $\mathrm{Fp} . \mathrm{Cr}$ at the doses of 50, 100 and $300 \mathrm{mg} / \mathrm{kg}$ reduced the castor oil-induced fluid accumulation to $100.30 \pm$ 0.47 ( $p<0.001$ vs. castor oil group), $89.32 \pm 0.86$ ( $p<$

Table 1 Effect of the Ficus palmata crude extract (Fp.Cr) and loperamide against castor oil induced diarrhea in mice

\begin{tabular}{lll}
\hline $\begin{array}{l}\text { Treatment } \\
(\mathrm{mg} / \mathrm{kg})\end{array}$ & $\begin{array}{l}\text { No of mice (out } \\
\text { of 5) with diarrhea }\end{array}$ & $\begin{array}{l}\text { Protection } \\
(\%)\end{array}$ \\
\hline Saline $(10 \mathrm{~mL} / \mathrm{kg})+$ castor oil & 5 & 0 \\
Fp.Cr $(50 \mathrm{mg} / \mathrm{kg})+$ castor oil & 4 & 20 \\
Fp.Cr $(100 \mathrm{mg} / \mathrm{kg})+$ castor oil & $2^{*}$ & 60 \\
Fp.Cr $(300 \mathrm{mg} / \mathrm{kg})+$ castor oil & $1^{*}$ & 80 \\
Loperamide $(10 \mathrm{mg} / \mathrm{kg})+$ castor oil & $0^{* *}$ & 100 \\
\hline
\end{tabular}

${ }^{*} p<0.05,{ }^{* *} p<0.01$ compared to saline group, data analyzed by Chi-squared test

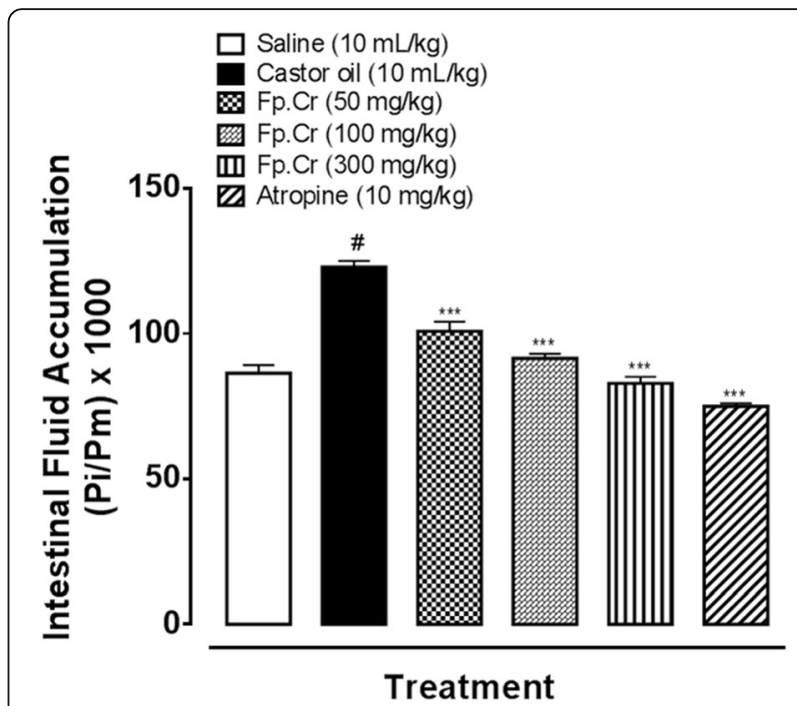

Fig. 3 Inhibitory effect of Ficus palmata crude extract (Fp.Cr) and atropine on castor oil induced fluid accumulation in mice. Results are expressed as mean $\pm \mathrm{SEM}, n=5$. Anti-secretory effect is expressed as $\mathrm{Pi} / \mathrm{Pm} \times 1000 \mathrm{~g}$ ) where $\mathrm{Pi}$ is the weight of the small intestine and Pm is the weight of mouse; ${ }^{\#} p<0.001$ vs. saline group, ${ }^{* * *} p<0.001$ vs. castor oil group, one-way analysis of variance with post-hoc Tukey's test

0.001 vs. castor oil group) and $80.98 \pm 0.67(p<0.001$ vs. castor oil group) respectively. Atropine at the dose of $10 \mathrm{mg} / \mathrm{kg}$ decreased the intestinal fluid accumulation to $74.34 \pm 0.69(P<0.001$ vs. castor oil group $)$ as shown in Fig. 3.

\section{Effect on spontaneous and $\mathrm{K}^{+}$induced contractions}

Figure 6 shows comparative inhibitory effect of the plant extract and verapamil against spontaneous and $\mathrm{K}^{+}(80 \mathrm{mM})$-induced contractions. Fp.Cr was found to be equally effective against spontaneous and $\mathrm{K}^{+}(80$ $\mathrm{mM}$ )-induced contractions with $\mathrm{EC}_{50}$ values of 0.11 $\mathrm{mg} / \mathrm{mL}(0.08-0.1, n=4)$ and $0.16 \mathrm{mg} / \mathrm{mL}(0.09-0.2$, $\mathrm{n}=4$ ) respectively as shown in Fig. 4a. With $\mathrm{EC}_{50}$ value of $0.04 \mu \mathrm{M} \quad(0.03-0.06, \mathrm{n}=4)$, verapamil was found more potent against $\mathrm{K}^{+}(80 \mathrm{mM})$-induced contractions, as compared to spontaneous contractions [0.12 $\mu \mathrm{M}(0.10-0.20, n=3)]$ as shown in Fig. 4b.

\section{Effect on ethanol-HCl induced ulcer}

Fp.Cr in dose dependent manner $(50-300 \mathrm{mg} / \mathrm{kg})$ exhibited an anti-ulcer effect. Fp.Cr at 50, 100 and 300 $\mathrm{mg} / \mathrm{kg}$ caused $21.1,42.2$ and $73.3 \%(p<0.001$ vs. saline group) inhibition respectively. Omeprazole (20 $\mathrm{mg} / \mathrm{kg}$ ) showed $88.8 \%$ protective effect (Table 2). Macroscopic observation showed the gastric mucosa of rats (Fig. 5). 

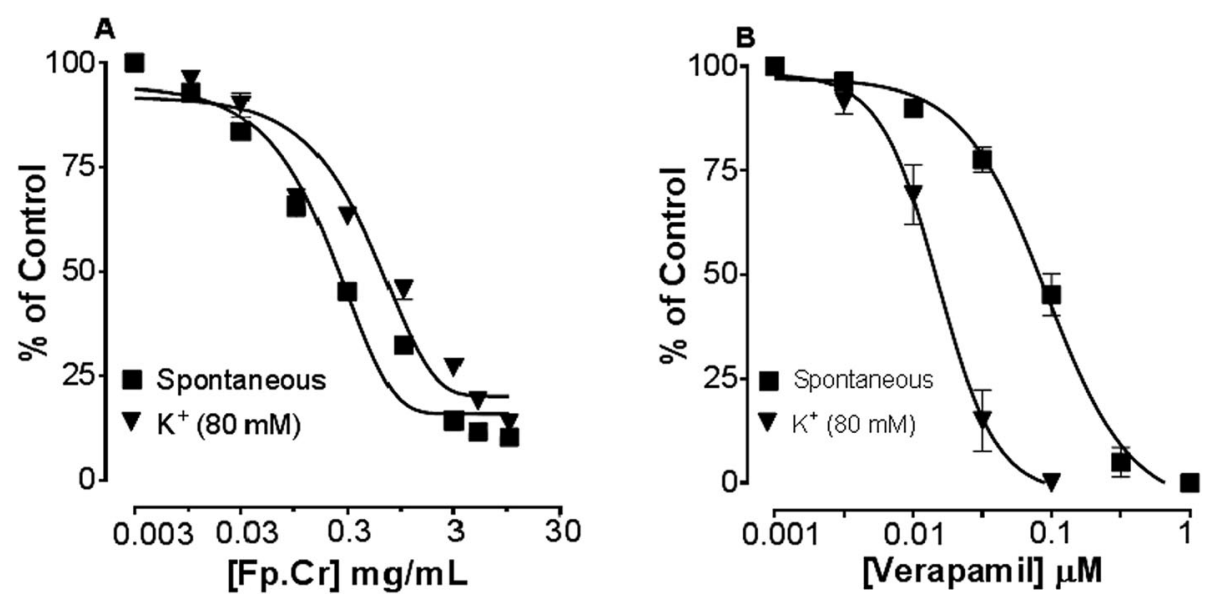

Fig. 4 Dose-dependent inhibitory effect on spontaneous and $\mathrm{K}^{+}(80 \mathrm{mM})$ induced contractions of (a) Ficus palmata crude extract (Fp.Cr) and (b) verapamil in isolated tissue preparations. Result expressed as mean $\pm \mathrm{SEM}, n=3-5$

\section{Effect on charcoal meal transit time}

Fp.Cr hinders the charcoal meal to travel through the small intestine in a dose dependent manner. The distance travelled by the saline group was $82.29 \%$. Fp.Cr at 50, 100 and $300 \mathrm{mg} / \mathrm{kg}$ dose shows inhibition of charcoal meal transit by 50.84, 48.46 and $45.87 \%$ respectively ( $p<0.001$ vs. saline group). Atropine $(0.1 \mathrm{mg} / \mathrm{kg}$, i.p. $)$ shows inhibitory effect of 44.23\% (Table 3).

\section{Docking evaluation}

Assessment of E-value is an important contributor which helps in docking evaluation. Table 4 shows the values of atomic energy in $\mathrm{Kcal} / \mathrm{mol}$ for complexes formed between ligand and target receptor. Binding residues involved in the formation of polar hydrogen bonds and total number of hydrogen bonds is expressed in Table 5. Total number of pi-pi bonds and binding residues forming these bonds are represented in Table 6. Other hydrophobic bonding of best models for ligand-target complexes are represented in

Table 2 Protective effect of Ficus palmata crude extract (Fp.Cr) and omeprazole against ethanol-HCl induced gastric ulcers in rats

\begin{tabular}{llc}
\hline Treatment & Ulcer Index & \% Inhibition \\
\hline Saline $10 \mathrm{~mL} / \mathrm{kg}+$ Ethanol-HCl & $9.0 \pm 0.07$ & - \\
Fp.Cr $(50 \mathrm{mg} / \mathrm{kg})+$ Ethanol-HCl & $7.1 \pm 0.20^{* * *}$ & 21.1 \\
Fp.Cr $(100 \mathrm{mg} / \mathrm{kg})+$ Ethanol-HCl & $5.2 \pm 0.14^{* * *}$ & 42.2 \\
Fp.Cr $(300 \mathrm{mg} / \mathrm{kg})+$ Ethanol-HCl & $2.4 \pm 0.14^{* * *}$ & 73.3 \\
Omeprazole $(20 \mathrm{mg} / \mathrm{kg})+$ Ethanol-HCl & $1 \pm 0.11^{* * *}$ & 88.8 \\
\hline
\end{tabular}

${ }^{* * *} p<0.001$ compared to control saline group, one-way analysis of variance, followed by Post-hoc Tukey's test, $n=5$
Table 7. Formation of bonding and interaction by bergapten, psoralene, psoralenoside, germanicol acetate and standard drugs against adrenergic $\alpha_{1}$ receptor, muscarinic $M_{1}$, muscarinic $M_{3}$, dopaminergic $D_{2}$, calmodulin, mu-opioid, voltage gated L-Type calcium channel, histaminergic $\mathrm{H}_{1}$, histaminergic $\mathrm{H}_{2}$ and $\mathrm{H}^{+}$/ $\mathrm{K}^{+}$ATPase pump are shown in Figs. 6, 7, 8, 9, 10, $11,12,13,14$ and 15 respectively.

\section{Discussion}

Based on ethnopharmacological use of Ficus palmata in hyperactive gut diseases, such as colic and diarrhea, its extract was evaluated for the possible anti-diarrheal, anti-secretory, charcoal meal gastrointestinal motility and anti-ulcer effects in rodents. Isolated intestinal tissue was used for the elucidation of possible underlying mechanism(s) to rationalize aforementioned ethnomedicinal uses of the plant and it was further supported by virtual screening tools.

Fp.Cr demonstrated an excellent antidiarrheal activity against castor oil induced diarrhea similar to the effect produced by loperamide, a standard drug [13]. Castor oil cause increases in the peristaltic activity and induce permeability changes to electrolytes and water in the mucosal membrane of the small intestine similar to an effect which is associated with prostaglandin release. Ricinoleic acid which is an active metabolite of castor oil is another major factor in causing diarrhea through a series of actions including activation of small intestinal peristaltic activity with reduction of $\mathrm{Na}^{+} / \mathrm{K}^{+}$ATPase activity. These changes eventually results in disturbance in the intestinal mucosa, electrolyte permeability, hypersecretion of intestinal contents and a slogging of the transport time in the intestine [19]. Thus, a potential 

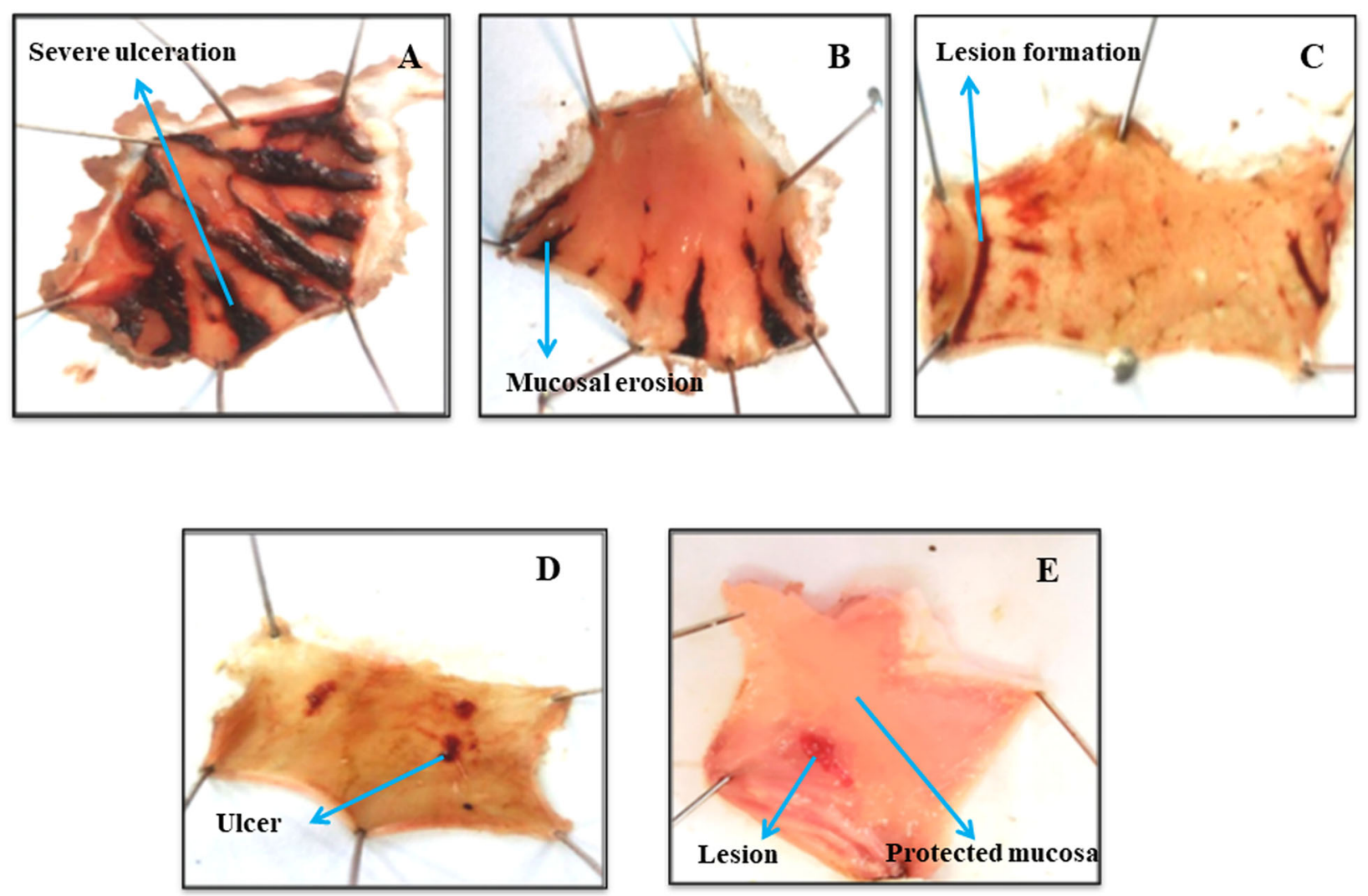

Fig. 5 Gross-appearance of gastric mucosa in rat: (a) pre-treated with saline, $10 \mathrm{~mL} / \mathrm{kg}$ (ulcer control). Severe injuries are seen, as ethanol-HCl (1 $\mathrm{mL} / 100 \mathrm{~g})$ produced excessive hemorrhagic necrosis of gastric-mucosa (b, c \& d) pretreated with Ficus palmata crude extract (Fp.Cr) at doses of $50,100,300 \mathrm{mg} / \mathrm{kg}$ and (e) pretreated with omeprazole $20 \mathrm{mg} / \mathrm{kg}$. The injuries reduce with increase of Fp.Cr doses and omeprazole compare with ulcer-control. At $300 \mathrm{mg} / \mathrm{kg}$, Fp.Cr showed most efficacious gastro protective action

agent may exhibit its anti-diarrheal activity by these mechanisms. Intracellular $\mathrm{Ca}^{2+}$ levels had a huge impact on secretary functions of the gastrointestinal organs which lead towards consequences such as discharge of gastric acids and intestinal fluid release. This effect might be affected by some drugs that hinder calcium influx [20]. Fp.Cr shows protection against castor oil induced intestinal fluid secretions in mice. The anti-diarrheal and anti-secretory activities of Fp.Cr might be because of gastrointestinal relaxant component(s) present in the Fp.Cr [10].
Dose-dependent inhibition of spontaneous contractions in isolated rabbit jejunum preparations were exhibited by $\mathrm{Fp} . \mathrm{Cr}$, thus showing antispasmodic action. High $\mathrm{K}^{+}(80 \mathrm{Mm})$, as $\mathrm{KCl}$, was used to depolarize the tissue to analyze whether the spasmolytic activity of this extract was mediated through calcium channel blockade or some other mechanism. High $\mathrm{K}^{+}(80$ $\mathrm{Mm})$ is known to cause smooth muscle contractions with opening of voltage gated L-type calcium channels, thus permitting the inflow of extracellular calcium causing contractility and the substance causing

Table 3 Effect of Ficus palmata crude extract (Fp.Cr) and atropine on charcoal meal transit time in rats

\begin{tabular}{llll}
\hline Treatment $(\mathrm{mg} / \mathrm{kg})$ & Mean length of Intestine $(\mathrm{cm})$ & Distance Moved by Charcoal $(\mathrm{cm})$ & Intestinal transit \% \\
\hline Saline $(10 \mathrm{~mL} / \mathrm{kg})$ & $86.00 \pm 0.3$ & $70.32 \pm 0.6$ & 82.29 \\
Fp.Cr $(50 \mathrm{mg} / \mathrm{kg})$ & $88.66 \pm 0.5$ & $45.08 \pm 0.4^{* * *}$ & 50.84 \\
Fp.Cr $(100 \mathrm{mg} / \mathrm{kg})$ & $86.66 \pm 0.4$ & $42.00 \pm 0.3^{* * *}$ & 48.46 \\
Fp.Cr $(300 \mathrm{mg} / \mathrm{kg})$ & $87.00 \pm 0.4$ & $40.00 \pm 0.5^{* * *}$ & 45.87 \\
Atropine $(0.1 \mathrm{mg} / \mathrm{kg}$, i.p.) & $90.8 \pm 0.6$ & $38.32 \pm 0.4^{* * *}$ & 44.23
\end{tabular}


Table 4 E-values (Kcal/mol) of best docked poses of bergapten, psoralene, psoralenoside, germanicol acetate and standard drugs against targets: adrenergic $a_{1}$ receptor, muscranic $M_{1}$, muscranic $M_{3}$, dopaminergic $D_{2}$, calmodulin, mu-opioid, voltage gated L-Type calcium channel, histaminergic $\mathrm{H}_{1}$, histamergic $\mathrm{H}_{2}$ and $\mathrm{H}^{+} / \mathrm{K}^{+}$ATPase pump

\begin{tabular}{|c|c|c|c|c|c|c|}
\hline Target Proteins & PDB ID & Bargapten & Psoralene & Psoralenoside & Germanicol acetate & Standard drugs \\
\hline Adrenergic $a_{1}$ & 3538 & -7.7 & -8.1 & -7.0 & 10.3 & $-8.0^{\mathrm{A}}$ \\
\hline Muscranic $M_{1}$ & $5 \mathrm{CXV}$ & -8.1 & -8.2 & -7.8 & -10.5 & $-9.0^{B}$ \\
\hline Muscranic $M_{3}$ & $4 \cup 14$ & -7.5 & -7.6 & -7.9 & -9.7 & $-8.6^{C}$ \\
\hline Dopaminergic $D_{2}$ & $6 \mathrm{CM} 4$ & -7.4 & -8.7 & -7.3 & 9.7 & $-10.6^{\mathrm{D}}$ \\
\hline Calmodulin & $1 \mathrm{CTR}$ & -5.8 & -5.8 & -6.0 & -9.2 & $-8.3^{\mathrm{E}}$ \\
\hline Calcium channel & $1 T 3 S$ & -6.2 & -6.2 & -6.5 & -9.2 & $-7.9^{F}$ \\
\hline Histaminergic $\mathrm{H}_{1}$ & $3 R Z E$ & -6.6 & -6.5 & -7.0 & -9.0 & $-5.7^{\mathrm{G}}$ \\
\hline $\mathrm{H}^{+} / \mathrm{K}^{+}$ATPase & $5 Y L U$ & -7.4 & -8.7 & -8.6 & -9.6 & $-8.4^{H}$ \\
\hline Histaminergic $\mathrm{H}_{2}$ & P25021 & -8.2 & -8.2 & -8.0 & -9.2 & $-6.1^{\prime}$ \\
\hline Mu Opioid & $5 \mathrm{C} 1 \mathrm{M}$ & -7.3 & -7.4 & -7.7 & -9.3 & $-9.2^{J}$ \\
\hline
\end{tabular}

Standard inhibitors or activator of pathways are: (A) piranzapine, (B) phenoxy benzamine (C) atropine, (D) domperidone, (E) calmozolium, (F) verapamil, (G) pyrilimine, (H) omeprazole, (I) ranitidine and $(\mathrm{J})$ loperamide

Table 5 Hydrogen bonds (H-bonds) formed by bergapten, psoralene, psoralenoside, germanicol acetate and standard drugs against targets: adrenergic $a_{1}$ receptor, muscranic $M_{1}$, muscranic $M_{3}$, dopaminergic $D_{2}$, calmodulin, mu-opioid, voltage gated L-Type calcium channel, histaminergic $\mathrm{H}_{1}$, histamergic $\mathrm{H}_{2}$ and $\mathrm{H}^{+} / \mathrm{K}^{+}$ATPase pump

\begin{tabular}{|c|c|c|c|c|c|c|c|c|c|c|c|}
\hline \multirow[t]{2}{*}{ Target Proteins } & \multirow[t]{2}{*}{ PDB ID } & \multicolumn{2}{|c|}{ Bargapten } & \multicolumn{2}{|l|}{ Psoralene } & \multicolumn{2}{|c|}{ Psoralenoside } & \multicolumn{2}{|c|}{ Germanicol acetate } & \multicolumn{2}{|c|}{ Standard drugs } \\
\hline & & $\mathrm{H}$-bonds & Amino Acids & $\mathrm{H}$-bonds & Amino Acids & H-bonds & Amino Acids & $\mathrm{H}$-bonds & Amino Acids & $\mathrm{H}$-bonds & Amino Acids \\
\hline Adrenergic $a_{1}$ & 3538 & 0 & - & 4 & $\begin{array}{l}\text { SER 180(2) } \\
\text { THR } 181 \\
\text { THR } 102\end{array}$ & 5 & $\begin{array}{l}\text { THR } 78 \\
\text { THR } 323 \\
\text { ASP } 320 \\
\text { GLN } 9 \\
\text { GLY } 81\end{array}$ & 1 & THR 283 & $0^{\mathrm{A}}$ & - \\
\hline Muscranic $M_{1}$ & $5 C X V$ & 2 & $\begin{array}{l}\text { CYS } 407 \\
\text { SER } 109\end{array}$ & 1 & ASN 382 & 0 & - & 0 & - & $2^{B}$ & $\begin{array}{l}\text { ILE } 180 \\
\text { TYR } 381\end{array}$ \\
\hline Muscranic $M_{3}$ & $4 \cup 14$ & 1 & SER 151 & 0 & - & 2 & $\begin{array}{l}\text { GLU } 1011 \\
\text { ASP } 1010\end{array}$ & 1 & TYR 148 & $0^{C}$ & - \\
\hline Dopaminergic $D_{2}$ & $6 \mathrm{CM} 4$ & 1 & TYR 416 & 1 & SER 193 & 1 & SER 409 & 1 & ILE 403 & $2^{\mathrm{D}}$ & $\begin{array}{l}\text { TYR } 413 \\
\text { GLU } 95\end{array}$ \\
\hline Calmodulin & 1CTR & 0 & - & 0 & - & 3 & $\begin{array}{l}\text { GLU } 114 \\
\text { GLU } 14 \\
\text { GLU } 127\end{array}$ & 0 & - & $O^{E}$ & - \\
\hline Calcium channel & $1 \mathrm{~T} 3 \mathrm{~S}$ & 1 & ARG 168 & 1 & ARG 168 & 3 & $\begin{array}{l}\text { SER } 177 \\
\text { ASN } 123 \\
\text { ASP } 126\end{array}$ & 2 & $\begin{array}{l}\text { GLY } 178 \\
\text { SER } 177\end{array}$ & $2^{F}$ & $\begin{array}{l}\text { GLN } 1156 \\
\text { ILE } 381\end{array}$ \\
\hline Histaminergic $\mathrm{H}_{1}$ & 3RZE & 1 & TRP93 & 1 & TRP 93 & 4 & $\begin{array}{l}\text { SER } 128 \\
\text { ARG } 125 \\
\text { ASN } 63 \\
\text { ASN } 472\end{array}$ & 0 & - & $0^{G}$ & - \\
\hline $\mathrm{H}^{+} / \mathrm{K}^{+}$ATPase & $5 Y L U$ & 2 & $\begin{array}{l}\text { THR } 799 \\
\text { TYR } 308\end{array}$ & 1 & ARG 544 & 5 & $\begin{array}{l}\text { ALA } 730 \\
\text { ASP } 710 \\
\text { ASP } 369 \\
\text { SER } 477 \\
\text { ASN } 713\end{array}$ & 0 & - & $1^{\mathrm{H}}$ & SER 477 \\
\hline Histaminergic $\mathrm{H}_{2}$ & P25021 & 3 & $\begin{array}{l}\text { SER } 185 \\
\text { SER } 181 \\
\text { THR } 173\end{array}$ & 3 & $\begin{array}{l}\text { SER } 185 \\
\text { SER } 181 \\
\text { THR } 173\end{array}$ & 4 & $\begin{array}{l}\text { TYR } 275 \\
\text { CYS } 169 \\
\text { ASP } 170 \\
\text { THR } 173\end{array}$ & 0 & - & $2^{1}$ & THR 173 \\
\hline Mu Opioid & $5 \mathrm{C} 1 \mathrm{M}$ & 1 & HIS 297 & 1 & ASN 382 & 3 & $\begin{array}{l}\text { TYR } 1018 \\
\text { ASN } 1020 \\
\text { GLU } 1011\end{array}$ & 0 & - & $1^{\jmath}$ & TYR 128 \\
\hline
\end{tabular}

Standard inhibitors or activators are: (A) piranzapine, (B) phenoxy benzamine, (C) atropine, (D) domperidone, (E) calmozolium, (F) verapamil (G) omeprazole, (I) ranitidine, and (J) loperamide. Amino acids are: ALA, alanine; ARG, arginine; ASN, asparagine; ASP, aspartic acid; CYS, cysteine; GLN, glutamine; GLU, glutamic acid; GLY, glycine; HIS, histidine; ILE, isoleucine; LYS, lysine; MET, methionine; PHE, phenylalanine; PRO, proline; SER, serine; THR, threonine; TRP, tryptophan; TYR, tyrosine and VAL, valine 
Table 6 Pi-Pi bonds ( $\mathrm{p}$-p bonds) formed by Bargapten, Psoralene, Psoralenoside, Germanicol acetate and standard drugs against targets: adrenergic $a_{1}$ receptor, muscranic $M_{1}$, muscranic $M_{3}$, dopaminergic $D_{2}$, calmodulin, mu-opioid, voltage gated L-Type calcium channel, histaminergic $\mathrm{H}_{1}$, histaminergic $\mathrm{H}_{2}$ and $\mathrm{H}^{+} / \mathrm{K}^{+}$ATPase pump

\begin{tabular}{|c|c|c|c|c|c|c|c|c|c|c|c|}
\hline \multirow[t]{2}{*}{ Proteins } & \multirow[t]{2}{*}{ PDB ID } & \multicolumn{2}{|c|}{ Bargapten } & \multicolumn{2}{|c|}{ Psoralene } & \multicolumn{2}{|c|}{ Psoralenoside } & \multicolumn{2}{|c|}{ Germanicol acetate } & \multicolumn{2}{|c|}{ Standard drugs } \\
\hline & & $\begin{array}{l}\pi-\pi \\
\text { bonds }\end{array}$ & $\begin{array}{l}\text { Amino } \\
\text { Acids }\end{array}$ & $\begin{array}{l}\pi-\pi \\
\text { bonds }\end{array}$ & $\begin{array}{l}\text { Amino } \\
\text { Acids }\end{array}$ & $\begin{array}{l}\pi-\pi \\
\text { bonds }\end{array}$ & $\begin{array}{l}\text { Amino } \\
\text { Acids }\end{array}$ & $\begin{array}{l}\pi-\pi \\
\text { bonds }\end{array}$ & $\begin{array}{l}\text { Amino } \\
\text { Acids }\end{array}$ & $\begin{array}{l}\pi-\pi \\
\text { bonds }\end{array}$ & $\begin{array}{l}\text { Amino } \\
\text { Acids }\end{array}$ \\
\hline Adrenergic $a_{1}$ & 3538 & 2 & $\begin{array}{l}\text { TRP } 295 \\
\text { PHE } 299\end{array}$ & 1 & $\begin{array}{l}\text { PHE } 299 \\
\text { CYS } 181\end{array}$ & 1 & VAL 168 & 0 & - & $3^{A}$ & $\begin{array}{l}\text { PHE } 299 \\
\text { TRP } 295 \\
\text { PHE } 298\end{array}$ \\
\hline Muscranic $M_{1}$ & $5 \mathrm{CXV}$ & 2 & $\begin{array}{l}\text { TYR } 381 \\
\text { TYR } 106\end{array}$ & 3 & $\begin{array}{l}\text { TYR } 404 \\
\text { TRP } 378 \\
\text { CYS } 407\end{array}$ & 2 & $\begin{array}{l}\text { ALA } 363 \\
\text { LYS } 362\end{array}$ & 0 & - & $1^{\mathrm{B}}$ & TYR 404 \\
\hline Muscranic $M_{3}$ & $4 \cup 14$ & 1 & TYR 506 & 1 & TRP 503 & 1 & TYR 1018 & 0 & - & $0^{c}$ & - \\
\hline $\begin{array}{l}\text { Dopaminergic } \\
D_{2}\end{array}$ & $6 \mathrm{CM} 4$ & 4 & $\begin{array}{l}\text { TRP } 386 \\
\text { PHE } 386 \\
\text { PHE } 390 \\
\text { ASP } 114\end{array}$ & 4 & $\begin{array}{l}\text { PHE } 390 \\
\text { TRP } 386 \\
\text { PHE } 198 \\
\text { PHE } 389\end{array}$ & 2 & $\begin{array}{l}\text { THR } 412 \\
\text { TRP } 100\end{array}$ & 1 & TYR 408 & $4^{\mathrm{D}}$ & $\begin{array}{l}\text { ASP } 114 \\
\text { PHE } 389 \\
\text { LEU } 94 \\
\text { TRP } 100\end{array}$ \\
\hline Calmodulin & $1 \mathrm{CTR}$ & 2 & $\begin{array}{l}\text { MET } 124 \\
\text { PHE } 92\end{array}$ & 1 & LEU 105 & 2 & $\begin{array}{l}\text { GLU } 11 \\
\text { MET } 72\end{array}$ & 0 & - & $5^{\mathrm{E}}$ & $\begin{array}{l}\text { MET } 144 \\
\text { MET } 145 \\
\text { MET } 109 \\
\text { LEU } 105 \\
\text { PHE } 92\end{array}$ \\
\hline Calcium channel & $1 \mathrm{~T} 3 \mathrm{~S}$ & 3 & $\begin{array}{l}\text { LEU } 86 \\
\text { GLU } 87\end{array}$ & 2 & $\begin{array}{l}\text { ARG } 65 \\
\text { GLU } 87\end{array}$ & 0 & - & 0 & - & $1^{\mathrm{F}}$ & ARG 413 \\
\hline Histaminergic $\mathrm{H}_{1}$ & 3RZE & 2 & $\begin{array}{l}\text { ARG } 97 \\
\text { CYS } 180\end{array}$ & 2 & $\begin{array}{l}\text { ARG } 97 \\
\text { CYS } 180\end{array}$ & 0 & - & 0 & - & $2^{G}$ & $\begin{array}{l}\text { PHE } 1104 \\
\text { GLU } 1011\end{array}$ \\
\hline $\mathrm{H}^{+} / \mathrm{K}^{+}$ATPase & $5 Y L U$ & 1 & PHE 909 & 1 & GLY 611 & 1 & ASP 443 & 0 & - & $1^{\mathrm{H}}$ & ARG 544 \\
\hline Histaminergic $\mathrm{H}_{2}$ & P25021 & 2 & $\begin{array}{l}\text { PHE } 249 \\
\text { PHE } 171\end{array}$ & 3 & $\begin{array}{l}\text { PHE } 171 \\
\text { PHE } 249 \\
\text { VAL } 92\end{array}$ & 1 & PHE 171 & 0 & - & $2^{1}$ & $\begin{array}{l}\text { PHE } 267 \\
\text { VAL } 268\end{array}$ \\
\hline Mu Opioid & $5 \mathrm{C} 1 \mathrm{M}$ & 3 & $\begin{array}{l}\text { VAL } 300 \\
\text { MET } 151 \\
\text { TRP } 293\end{array}$ & 3 & $\begin{array}{l}\text { TYR } 494 \\
\text { CYS } 407 \\
\text { TRP } 378\end{array}$ & 2 & $\begin{array}{l}\text { THR } 1142 \\
\text { ARG } 1145\end{array}$ & 1 & PHE 239 & $3^{j}$ & $\begin{array}{l}\text { ILE } 296 \\
\text { HIS } 297 \\
\text { TRP } 293\end{array}$ \\
\hline
\end{tabular}

Standard inhibitors or activators are: $(A)$ phenoxy benzamine, $(B)$ piranzapine, $(C)$ atropine, $(D)$ domperidone, $(E)$ calmozolium, $(F)$ verapamil, $(G)$ pyrilimine, $(H)$ omeprazole, (I) ranitidine and (J) loperamide. Amino acids are: ALA, alanine; GLN, glutamine; GLY, glycine; HIS, histidine; LYS, lysine; PHE, phenylalanine; SER, Serine; TRP, tryptophan and TYR, tyrosine and VAL, valine

this inhibition of high $\mathrm{K}^{+}$-induced contractions is considered as calcium channel blocker [15]. Verapamil, a specific calcium antagonist have inhibitory effect against $\mathrm{K}^{+}$-induced contractions. Against spontaneous and $\mathrm{K}^{+}$-induced contractions $\mathrm{Fp}$.Cr produces inhibitory pattern just like verapamil.

Gastric ulcer is the result of an imbalance between aggressive and defensive factors of the gastric mucosa which results in rupturing of mucosal protection and expose gastric lining to gastric acids. To explore the anti-ulcer effect of $\mathrm{Fp} . \mathrm{Cr}$, ethanol-HCl induced gastric model was used which through variety of mechanisms stimulates ulcer including mucus exhaustion, mucosal damage, release of superoxide anion, hydro-peroxy free radicals, all these mechanisms prolonged the tissue oxidative stress and release of inflammatory mediators. Fp.Cr significantly decreased the surface ulceration as compared to that of control animals which received saline. In view of these results, methanol extract showed significant cytoprotection. The potential of $\mathrm{Fp}$.Cr to produce anti-ulcer effect might be due to its $\mathrm{CCB}$ effect, as $\mathrm{Ca}^{2+}$ antagonist are well known to demonstrate such effects [21]. In pathophysiology of gastric ulcers, oxidative stresss plays a vital role. Antioxidant and nitric oxide free scaveneging activity has been reported by Ficus palmata [10] which may be responsible for its effectiveness as anti-ulcer agent.

Intestinal transit travelling, an important measurement factor that regulates the bioavailability of orally administered drugs/foods and determines the absorption intensity of luminal contents. More oftenly, timely oral administration of active charcoal, as marker, to experimental animals are useful to measure the intestinal transit rate. This experimental model is sensitive to agents that inhibit/stimulate intestinal peristalsis regulated by autonomic nervous system. This is the rationale for using this assay to 
Table 7 Hydrophobic interactions formed by bergapten, psoralene, psorelenoside, germanicol acetate and standard drugs against targets: adrenergic $a_{1}$ receptor, muscranic $M_{1}$, muscranic $M_{3}$, dopaminergic $D_{2}$, calmodulin, mu-opioid, voltage gated L-Type calcium channel, histaminergic $\mathrm{H}_{1}$, histamergic $\mathrm{H}_{2}$ and $\mathrm{H}^{+} / \mathrm{K}^{+}$ATPase pump

\begin{tabular}{|c|c|c|c|c|c|c|}
\hline $\begin{array}{l}\text { Target } \\
\text { proteins }\end{array}$ & PDB ID & Bargapten & Psoralene & Psoralenoside & Germanicol acetate & Standard drugs \\
\hline Adrenergica $_{1}$ & 3538 & $\begin{array}{l}\text { ALA 184CYS } \\
\text { 101ILE } 98 \\
\text { VAL } 169\end{array}$ & $\begin{array}{l}\text { VAL 169ALA } \\
\text { 184ILE } 98\end{array}$ & MET 305 & $\begin{array}{l}\text { ARG 276VAL 245,242MET } \\
\text { 273ALA 280,274 }\end{array}$ & $\begin{array}{l}\text { ALA 184LE 98CYS 101VAL } \\
\text { 169VAL 168_ }\end{array}$ \\
\hline Muscranic $\mathrm{M}_{1}$ & $5 \mathrm{CXV}$ & - & ALA 196 & - & $\begin{array}{l}\text { ILE 119LEU 64,367ALA } \\
\text { 363ARG } 123\end{array}$ & LEU 183TYR 106_ \\
\hline Muscranic $M_{3}$ & $4 \cup 14$ & ALA 238, CYS 532 & CYS 532ALA 238 & ARG 1014 & $\begin{array}{l}\text { ILE 128,222TYR 127,506ASN } \\
\text { 526,131TRP } 525\end{array}$ & $\begin{array}{l}\text { TYR 533, 529CYS 532TRP } \\
\text { 503VAL 155ALA 238C }\end{array}$ \\
\hline $\begin{array}{l}\text { Dopaminergic } \\
D_{2}\end{array}$ & $6 \mathrm{CM} 4$ & CYS 118HIS 393 & $\begin{array}{l}\text { VAL 115CYS } \\
118 A L A 122\end{array}$ & VAL 91TYR 408 & $\begin{array}{l}\text { TYR 416LEU 94ILE 184TRP } \\
100\end{array}$ & $\begin{array}{l}\text { PHE 202ILE 383TYR } \\
\text { 213ALA 376GLN 373 }\end{array}$ \\
\hline Calmodulin & $1 \mathrm{CTR}$ & $\begin{array}{l}\text { LEU 105MET 144ILE } \\
\text { 100ALA 128VAL } 136\end{array}$ & $\begin{array}{l}\text { ILE 100ILE 125VAL } \\
136\end{array}$ & ALA 15 & $\begin{array}{l}\text { ILE 119LEU 347,64ALA } \\
\text { 363VAL } 127\end{array}$ & $\begin{array}{l}\text { PHE 19LEU 116LEU 18ALA } \\
\text { 15VAL 136ALA 100 }\end{array}$ \\
\hline $\begin{array}{l}\text { Calcium } \\
\text { channel }\end{array}$ & $1 \mathrm{~T} 3 \mathrm{~S}$ & - & - & LYS 51THR 55GLU 49 & VAL 48LEU 24,58TYR 108 & $\begin{array}{l}\text { LYS 1170THR 1471ASP } \\
\text { 1468TYR 1163 }\end{array}$ \\
\hline $\begin{array}{l}\text { Histaminergic } \\
\mathrm{H}_{1}\end{array}$ & 3RZE & $\begin{array}{l}\text { ASP 91VAL 95VAL } \\
\text { 92ASN } 252\end{array}$ & ASN 252VAL 95 & ASP 91ASN 252 & $\begin{array}{l}\text { GLY 239TYR 201MET } \\
\text { 238LEU 198,231ALA 197, } \\
204\end{array}$ & $\begin{array}{l}\text { ALA 1074ALA 1073LEU } \\
1032_{-}^{\mathbf{G}}\end{array}$ \\
\hline $\mathrm{H}^{+} / \mathrm{K}^{+}$ATPase & $5 Y L U$ & $\begin{array}{l}\text { VAL 798ARG } \\
\text { 972GLY } 796\end{array}$ & $\begin{array}{l}\text { LYS 501LYS } \\
\text { 480ALA 503GLY } \\
611\end{array}$ & $\begin{array}{l}\text { GLY 711VAL 712LYS } \\
\text { 187THR } 371\end{array}$ & $\begin{array}{l}\text { LYS 719VAL 243PRO 716, } \\
688\end{array}$ & $\begin{array}{l}\text { GLY 245PHE 475VAL } \\
\text { 712ASN 713LYS 187_ }\end{array}$ \\
\hline $\begin{array}{l}\text { Histaminergic } \\
\mathrm{H}_{2}\end{array}$ & P25021 & $\begin{array}{l}\text { ASP 91VAL 95VAL } \\
92\end{array}$ & ASN 252VAL 95 & $\begin{array}{l}\text { GLY 239MET 238LEU } \\
\text { 198, 231HIS 228ALA } 197\end{array}$ & $\begin{array}{l}\text { ALA 269VAL 72, 268TRP } \\
265\end{array}$ & TYR 275ASN 271ALA 178'. \\
\hline Mu-Opioid & $5 \mathrm{C} 1 \mathrm{M}$ & ILE 296VAL 236 & SER 109ALA 196 & $\begin{array}{l}\text { ILE 198PHE 156LEU } \\
\text { 196ALA } 197\end{array}$ & $\begin{array}{l}\text { ILE 322, 296TRP 318VAL } \\
\text { 300HIS 319TYR } 128\end{array}$ & $\begin{array}{l}\text { ILE 296TYR 326VAL } \\
\text { 300MET 1511LE 322 }\end{array}$ \\
\hline
\end{tabular}

Standard inhibitors or activators are: (A) phenoxy benzamine, (B) piranzapine, (C) atropine, (D) domperidone, (E) calmozolium, (F) verapamil, (G) pyrilimine, (H) omeprazole, (I) ranitidine, and (J) loperamid.. Amino acids are: ALA, alanine; ARG, arginine; ASN, asparagine; ASP, aspartic acid; CYS, cysteine; GLN, glutamine; GLU, glutamic acid; GLY, glycine; HIS, histidine; ILE, isoleucine; LYS, lysine; MET, methionine; PHE, phenylalanine; PRO, proline; SER, serine; THR, threonine; TRP, tryptophan; TYR, tyrosine and VAL, valine

investigate the influence of natural products on intestinal peristalsis [22]. In the small intestinal transit test, Fp.Cr produces suppression of the propulsion of charcoal marker at all test doses just like atropine sulphate a standard drug, that has been reported to have anticholinergic effect on intestinal transit [21]. A decrease in the motility of gut muscles increases the stay of substances in the intestine, thus allows better water absorption. This finding suggests that $\mathrm{Fp} . \mathrm{Cr}$ has the ability to influence the peristaltic movement of intestine thereby indicating the presence of an anti-motility activity. It is therefore presumed that the reduction in the intestinal propulsive movement in the charcoal meal model may be due to antispasmodic properties of the Fp.Cr [22].

The observed therapeutic effects of Ficus palmata may be due to the presence of phytochemicals, tannins and flavonoids, as these phytocontinuents are well known for gastrointestinal effects. Anti-diarrheal, anti-secretory, anti-ulcer and anti-spasmodic activities may be due to flavonoids [23].

Molecular docking is an effective tool for evaluating the affinity of various protein targets that may possibly be associated with the pathophysiology of gastric disorders. The traditionally acclaimed use of Ficus palmata in the management of gastric related diseases has been supported with scientific evidence using virtual screening tool and different chemicallyinduced gastrointestinal models like castor oil induced diarrhea, castor oil induced enteropooling, and charcoal meal gastrointestinal motility. The use of computational methodologies has end up being fundamental component of drug discovery and development process therefore computational screening becomes broadly employed tool in identifying the potential of structural chemical compounds before initiation of wet lab research. Since early 90's, docking has been observed to play a primary role for virtual screening of different chemical structures and it is still an extremely dynamic region to look forward [24]. Lead compounds are virtually screened through molecular docking that turns out to be time saving as well as economically affordable on premise of structural conformations [25].

In this study, Auto Dock Vina program was used through PyRx [26]. Through gradient optimization 


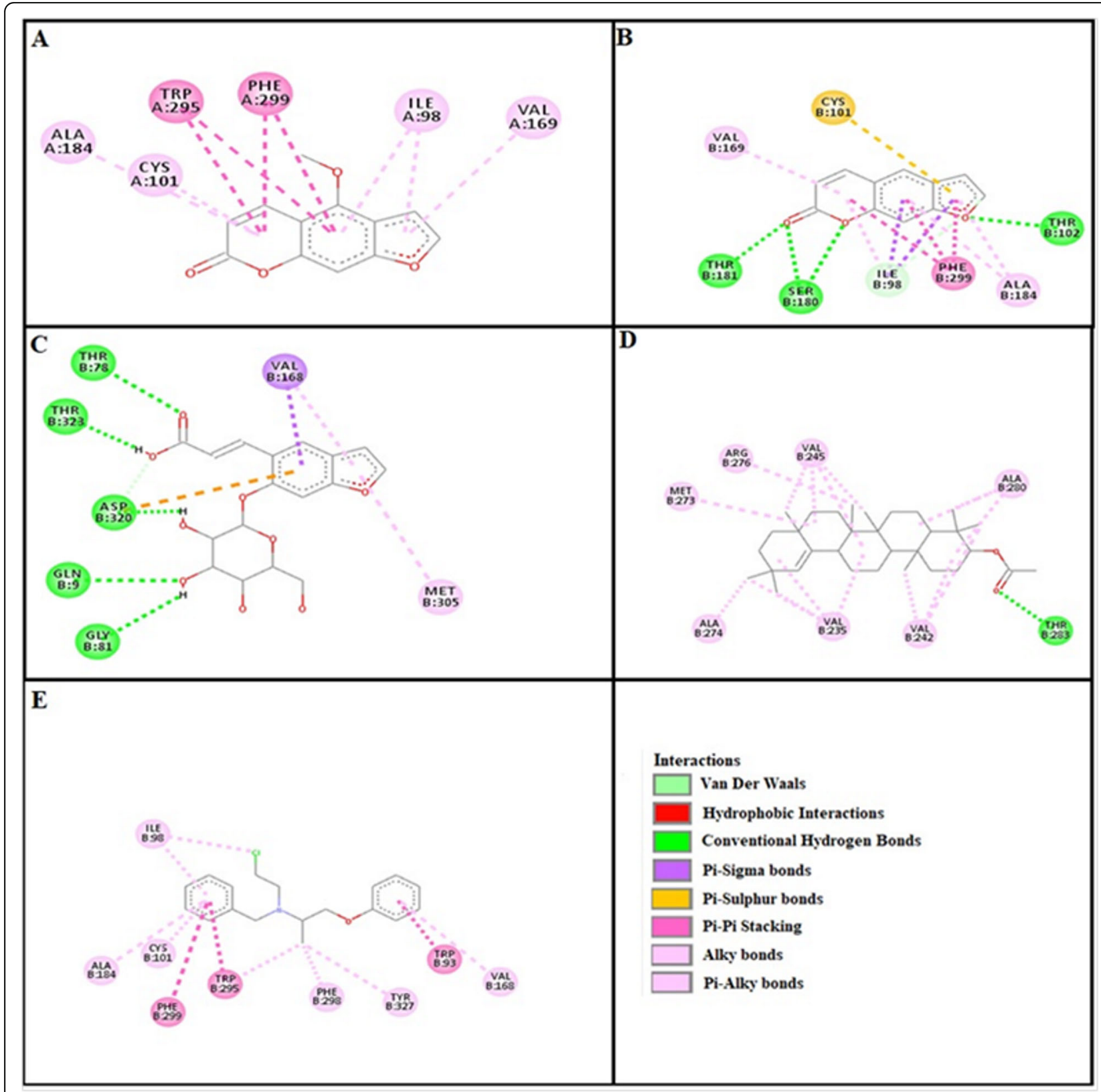

Fig. $\mathbf{6}$ a, b, c, $\mathbf{d}$ and (e) represents interactions of bergapten, psoralene, psoralenoside, germanicol acetate and phenoxy benzamine against target: adrenergic $a_{1}$ receptor respectively, evaluated through Biovia Discovery Studio 2016

method, binding mode predictions are improved. Evalue, Lower desolvation, Hydrogen bonding, pi-pi and other hydrophobic interactions imparts their influential effect in gastrointestinal diseases [27] which are contributing factors in increasing affinity with protein and stabilization of ligand-receptor complex. It has been found that psoralenoside showed excellent score of binding against $\alpha_{1}$ receptor with lowest E-value. This binding efficacy is greater than majority of the target proteins with better affinity as compared to other test compounds and standard drugs. Order of affinity of test compounds for $\alpha_{1}$ and $M_{1}$ receptor was; psoralenoside > bergapten > psoralene > germanicol acetate. Compounds with higher affinity all together formed stronger pi-pi bonds, high number of hydrophobic interactions and polar hydrogen bonding against muscarinic $M_{1}$ and $\alpha_{1}$ receptors. The order of affinity for ligands against muscranic $\mathrm{M}_{3}$ receptor was found as; bergapten > psoralene > psoralenoside > germanicol acetate. 


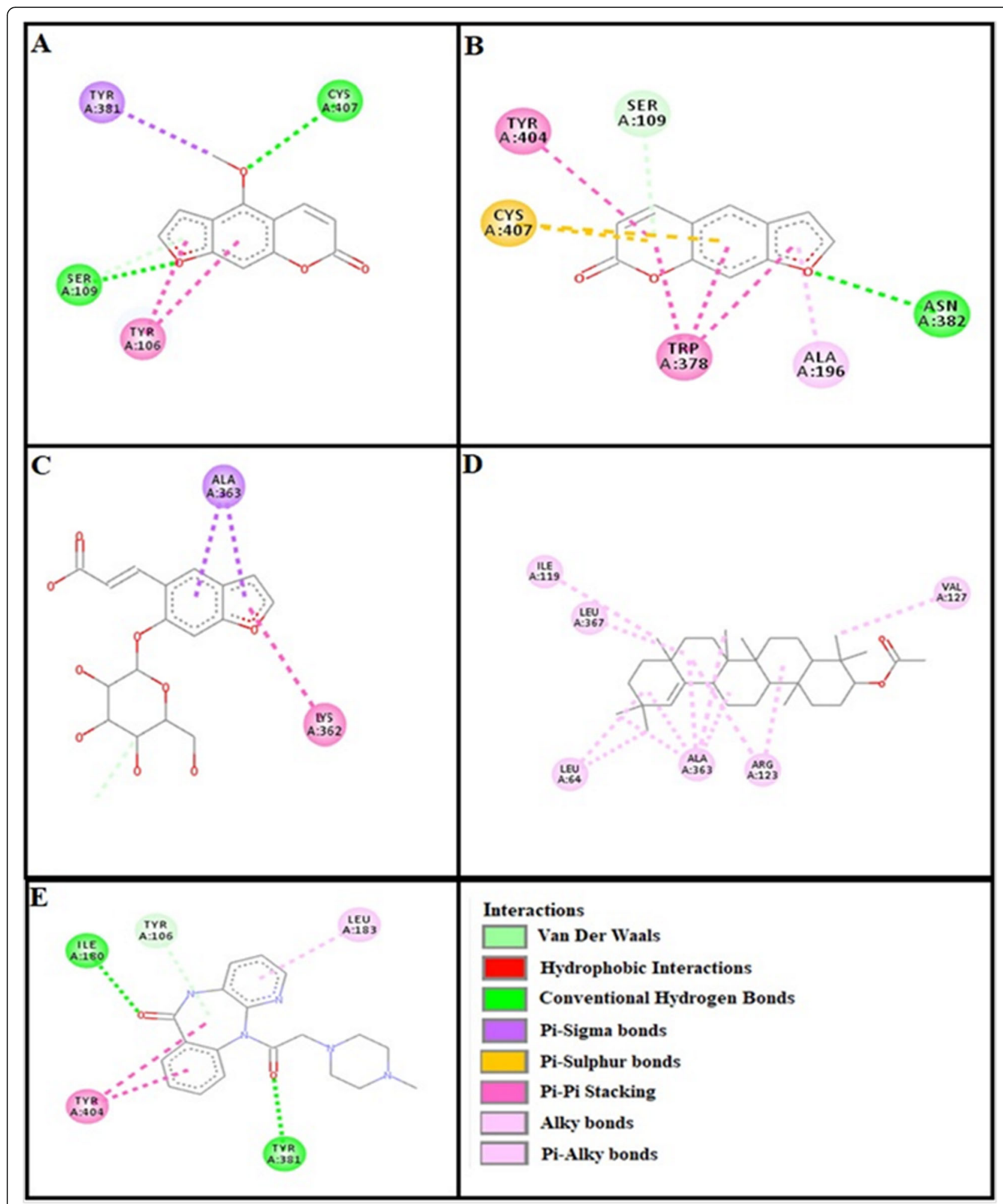

Fig. 7 a, b, c, d and (e) represents interactions of bergapten, psoralene, psoralenoside, germanicol acetate and piranzapine against target: muscranic $M_{1}$ receptor respectively, evaluated through Biovia Discovery Studio 2016 


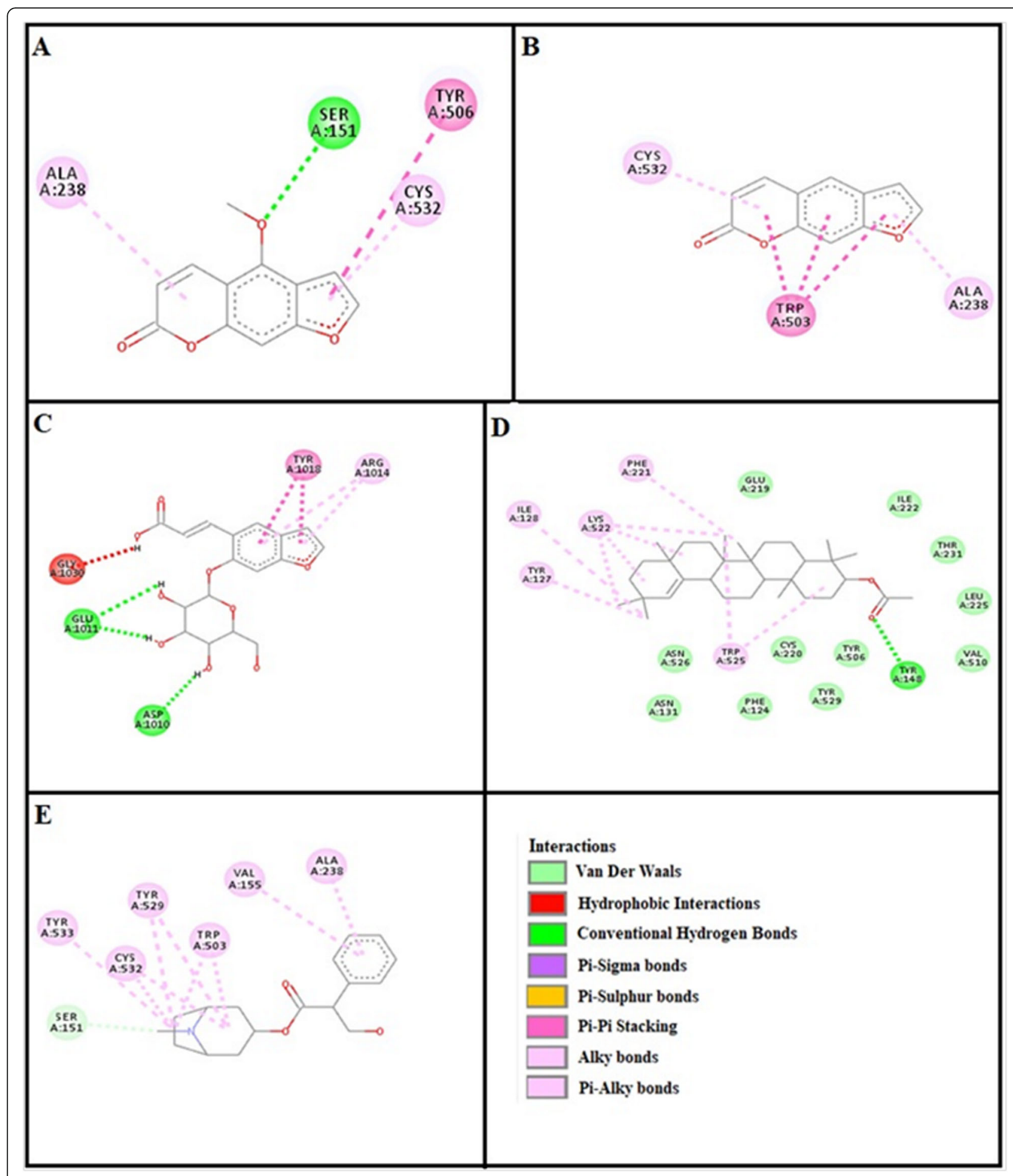

Fig. 8 a $\mathbf{b}, \mathbf{c}$, d and (e) represents interactions of bergapten, psoralene, psoralenoside, germanicol acetate and atropine against target: musranic $\mathrm{M}_{3}$ receptor respectively, evaluated through Biovia Discovery Studio 2016 


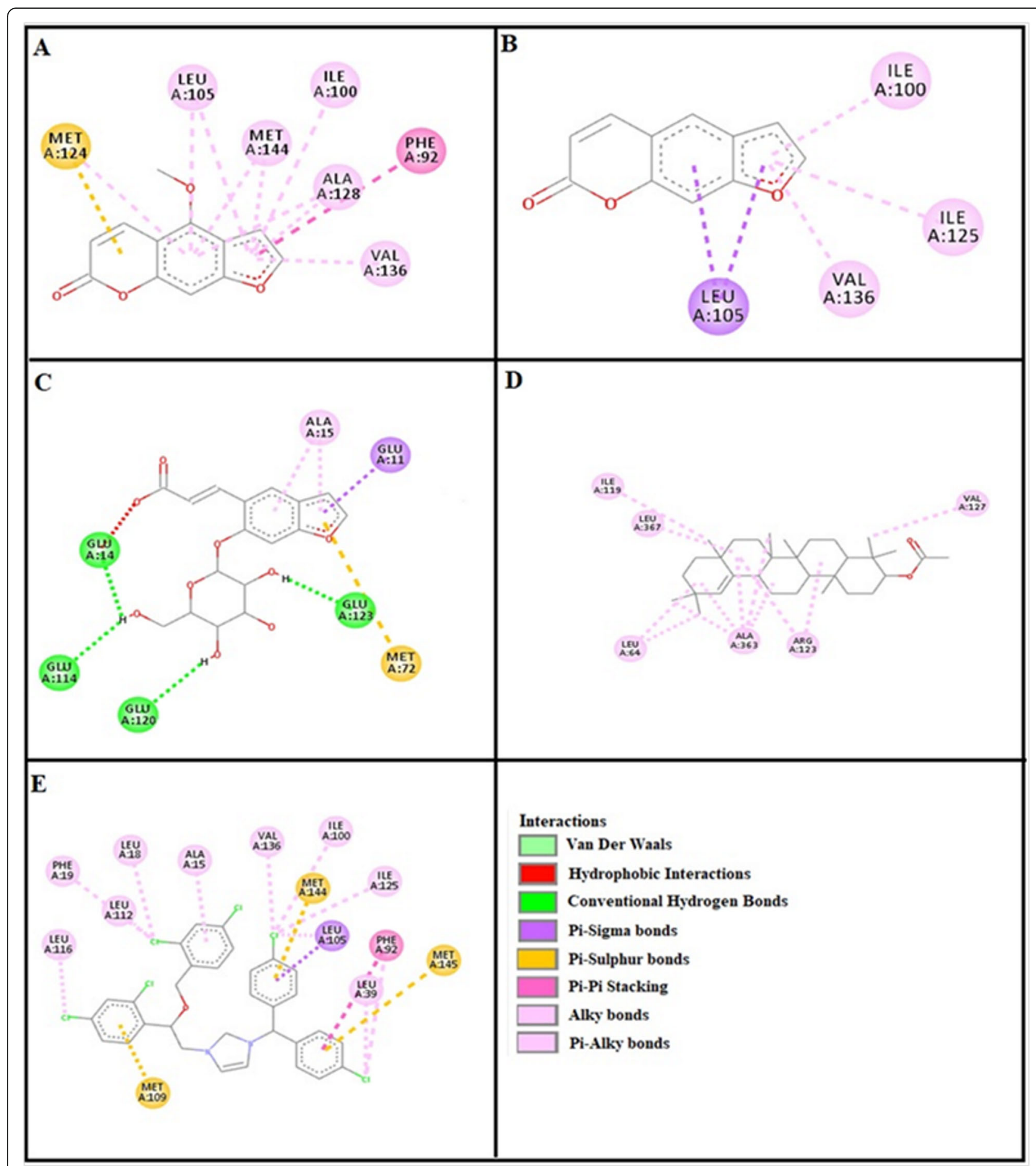

Fig. 9 a, b, c, $\mathbf{d}$ and (e) represents interactions of bergapten, psoralene, psoralenoside, germanicol acetate and domperidone against target: dopaminergic $D_{2}$ receptor respectively, evaluated through Biovia Discovery Studio 2016 


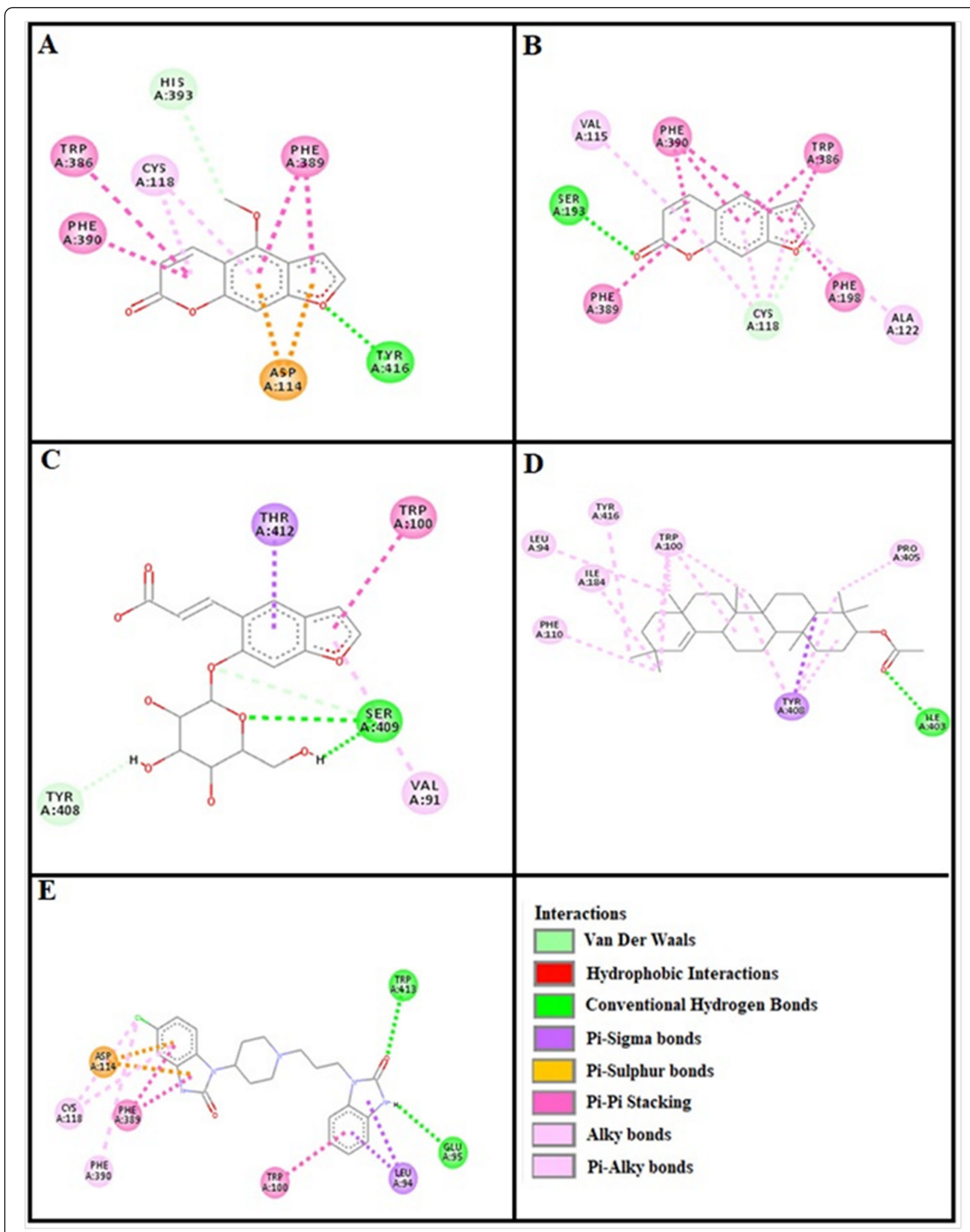

Fig. 10 a, b, c, $\mathbf{d}$ and (e) represents interactions bergapten, psoralene, psoralenoside, germanicol acetate and calmozolium against target: calmodulin receptor respectively, evaluated through Biovia Discovery Studio 2016 


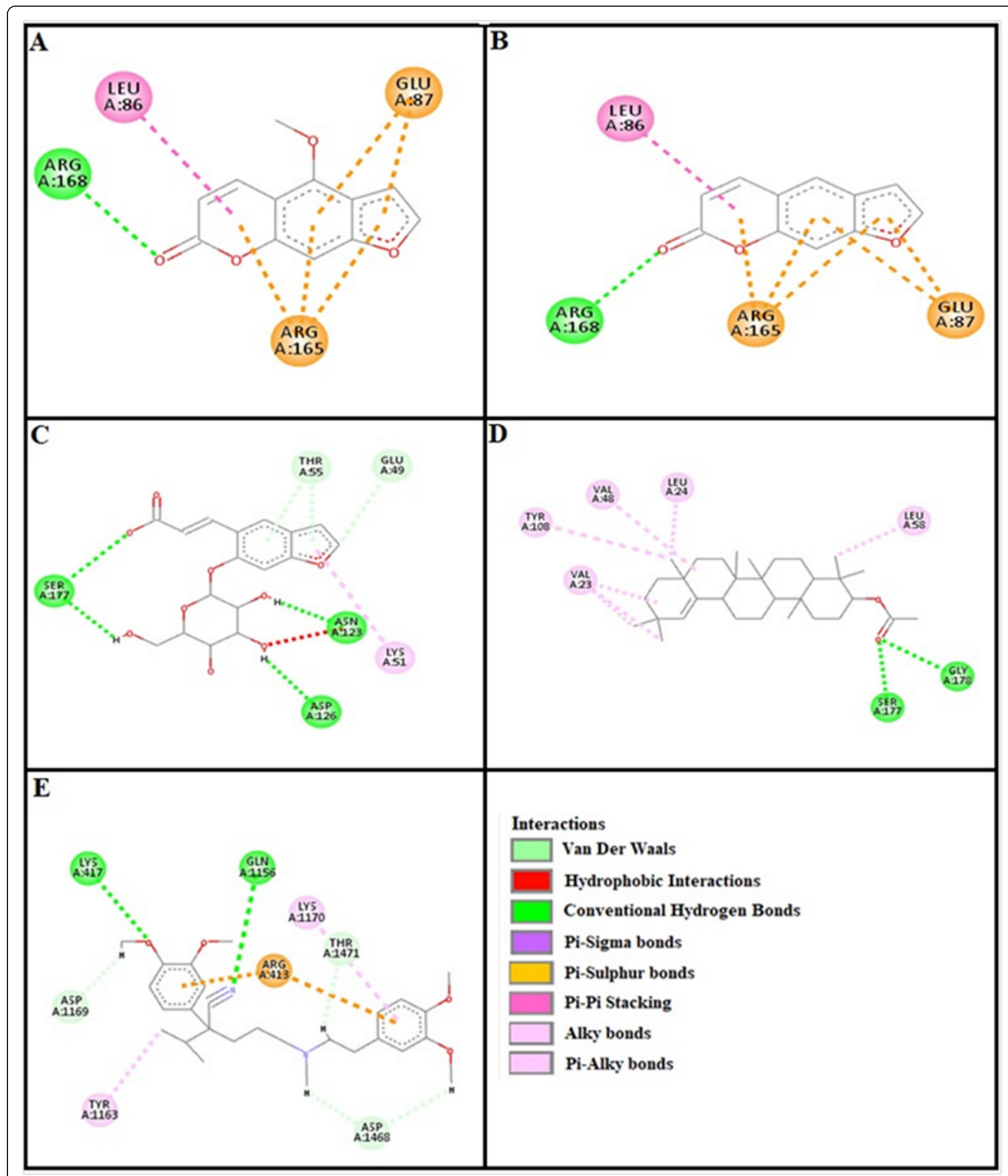

Fig. 11 a, b, c, d and (e) represents interactions of bergapten, psoralene, psoralenoside, germanicol acetate and verapamil against target: voltage gated L-Type calcium channels respectively, evaluated through Biovia Discovery Studio 2016 


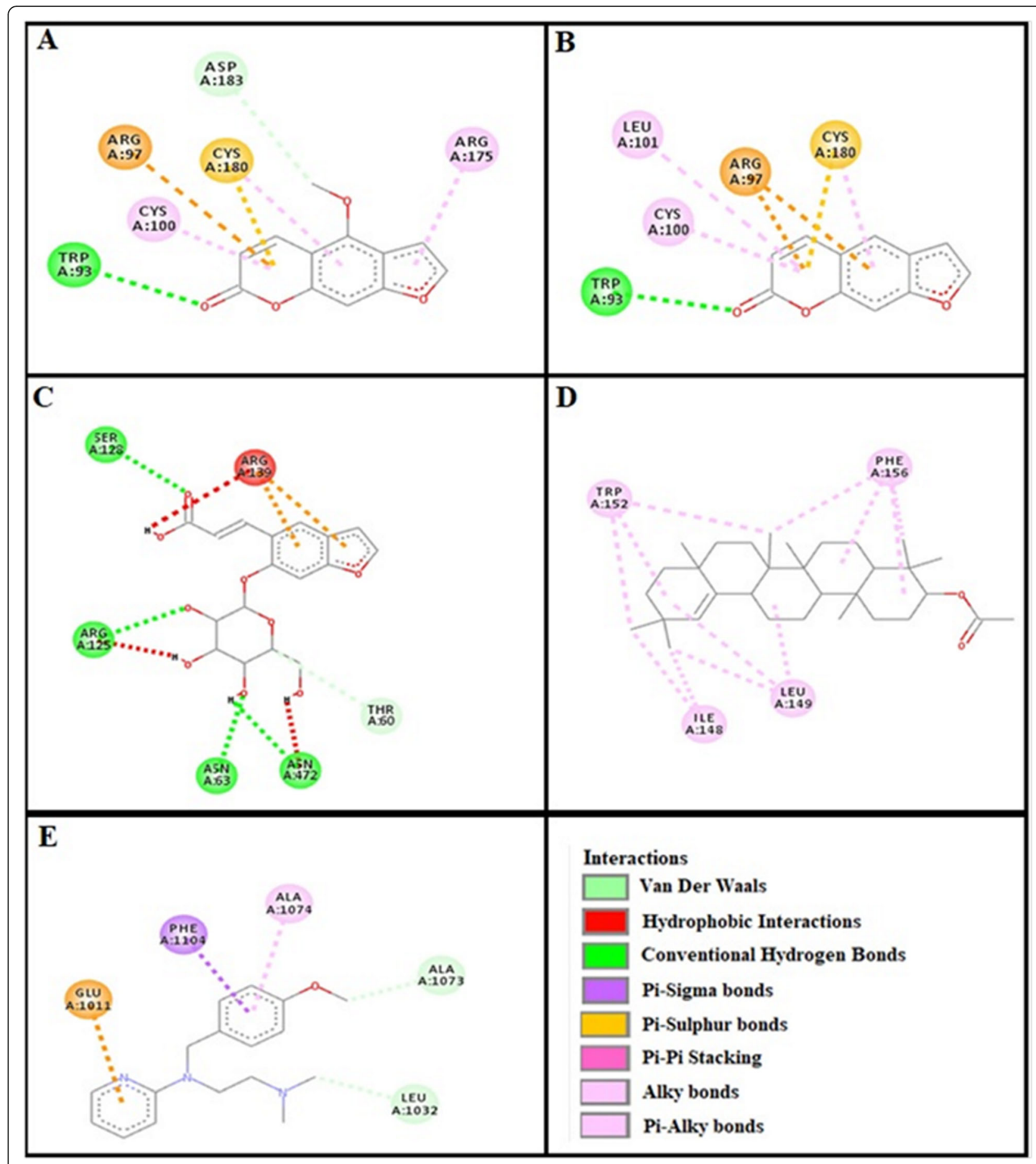

Fig. 12 a, b, c, d and (e) represents interactions of bergapten, psoralene, psoralenoside, germanicol acetate and pyrilimine against target: histaminergic $\mathrm{H}_{1}$ receptor respectively, evaluated through Biovia Discovery Studio 2016

Order of affinity of test compounds for dopaminergic $D_{2}$ receptor was found as; psoralenoside > bergapten > psoralene > germanicol acetate. Alongside hydrogen and hydrophobic interactions, different types of interactions, for example alky, pi-alky and vander waal interactions are appeared with high proclivity by test compounds. The affinity order of ligands against calmodulin was found as; bergapten > psoralene > psoralenoside $>$ germanicol acetate. In addition, hydrogen bond is considered to be vital for 


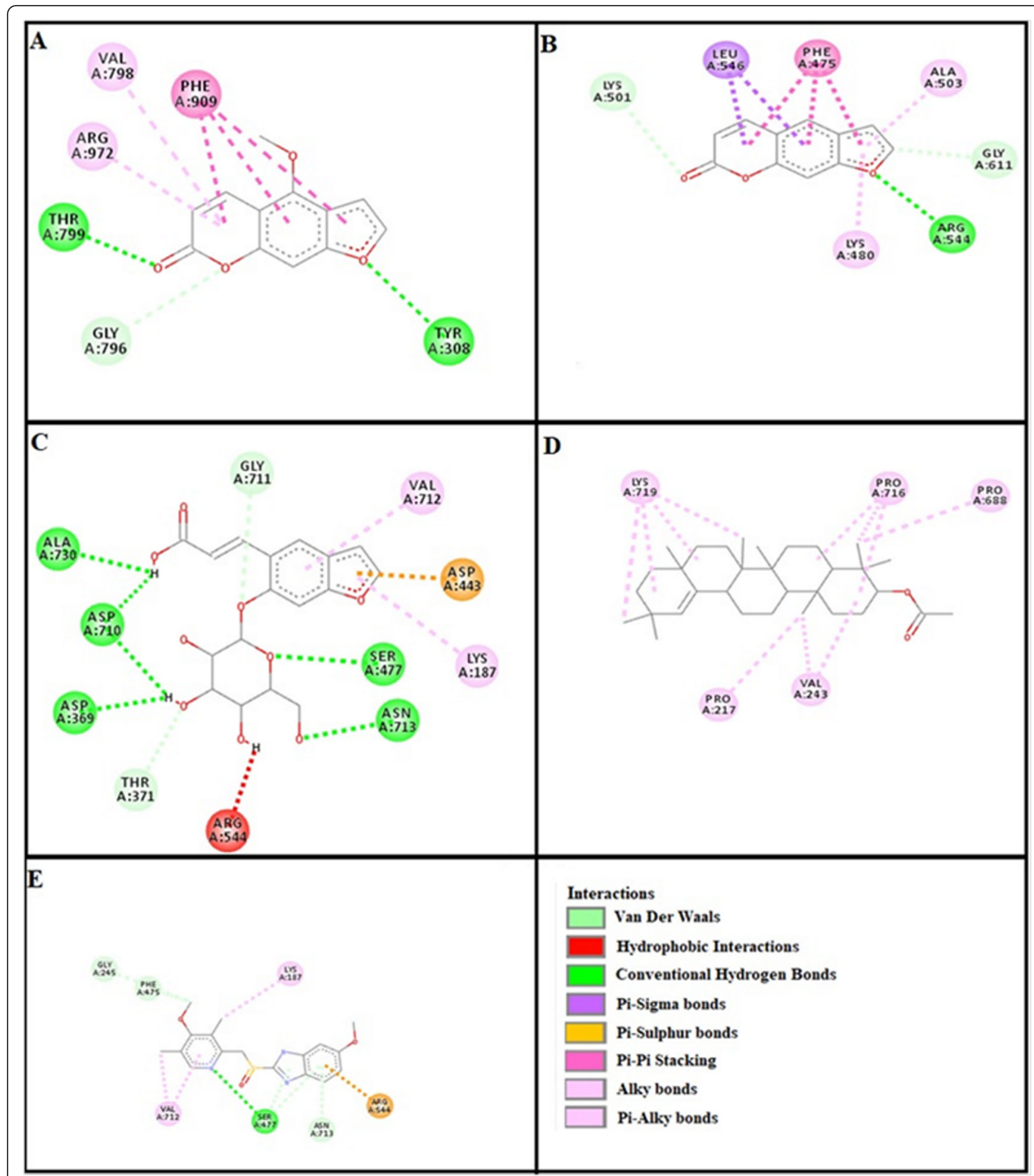

Fig. 13 a, b, c, d and (e) represents interactions of bergapten, psoralene, psoralenoside, germanicol acetate and omeprazole against target: $\mathrm{H}^{+} / \mathrm{K}^{+}$ ATPase receptor respectively, evaluated through Biovia Discovery Studio 2016

complex of ligand with calmodulin. The affinity order for test compounds for voltage gated L-Type calcium channel was found as; bergapten > psoralene $>$ psoralenoside > germanicol acetate. Order of affinity of test compounds for histaminergic $\mathrm{H}_{1}$ receptor was found to be: psoralene > bergapten > psoralenoside $>$ germanicol acetate. Ligands are not engaged with making any solid interactions on stated 


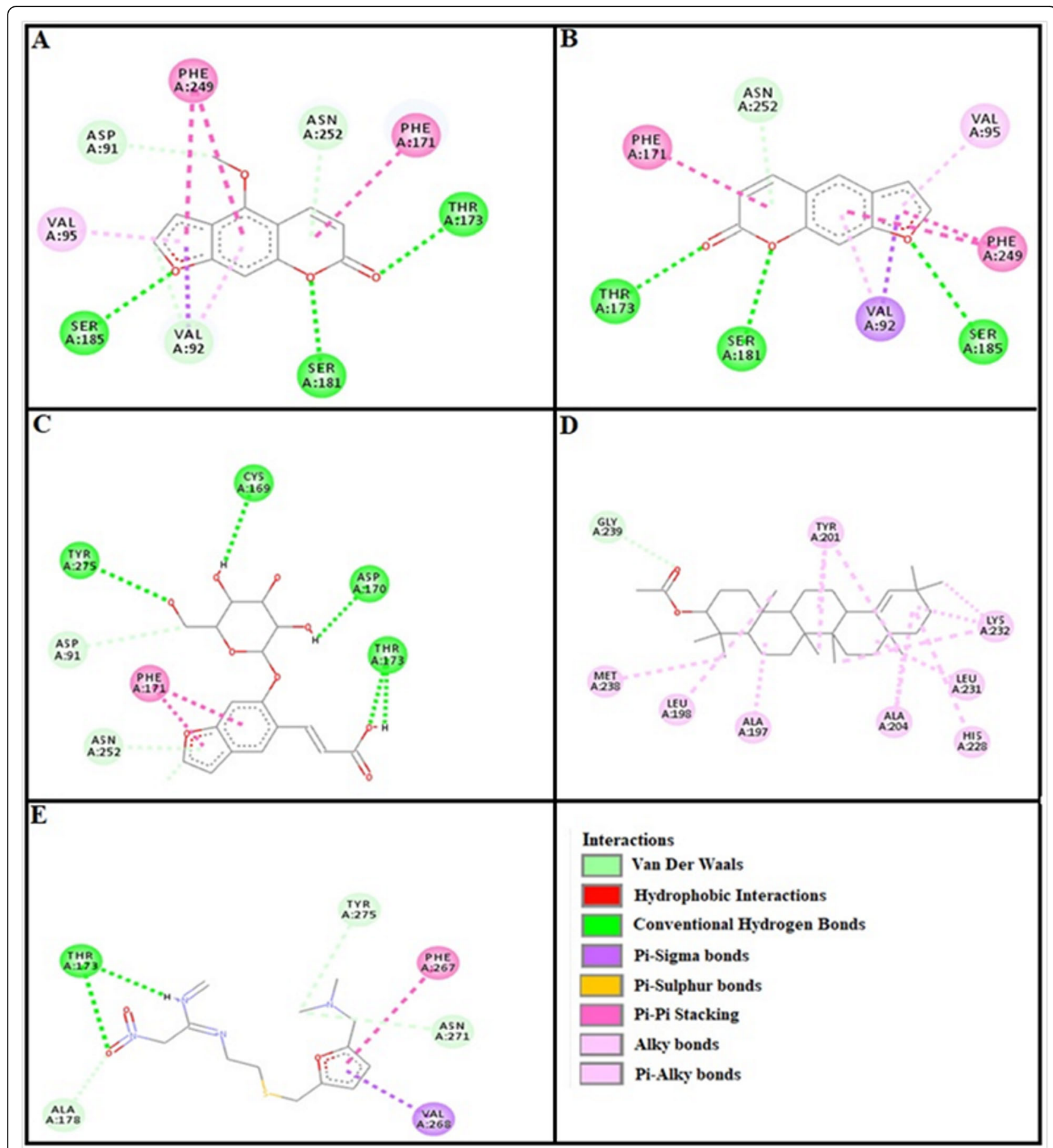

Fig. $14 \mathbf{a}, \mathbf{b}, \mathbf{c}, \mathbf{d}$ and (e) represents interactions of bergapten, psoralene, psoralenoside, germanicol acetate and ranitidine against target: histaminergic $\mathrm{H}_{2}$ receptor respectively, evaluated through Biovia Discovery Studio 2016

restricting sites. Order of affinity of test compounds for $\mathrm{H}^{+} / \mathrm{K}^{+}$ATPase receptor was found as; bergapten $>$ psoralenoside > psoralene > germanicol acetate. Hydrogen and hydrophobic associations are observed to be essential but no such interactions of test compounds with stated restricting site were seen [28]. In this regard, SER 477 is considered as important and vital amino acid. The affinity order of ligands against histaminergic $\mathrm{H}_{2}$ receptor was found as; psoralenoside > psoralene $>$ bergapten $>$ germanicol acetate. Order of affinity of test compounds for mu-opioid receptor was found as: bergapten > psoralene > psoralenoside > 


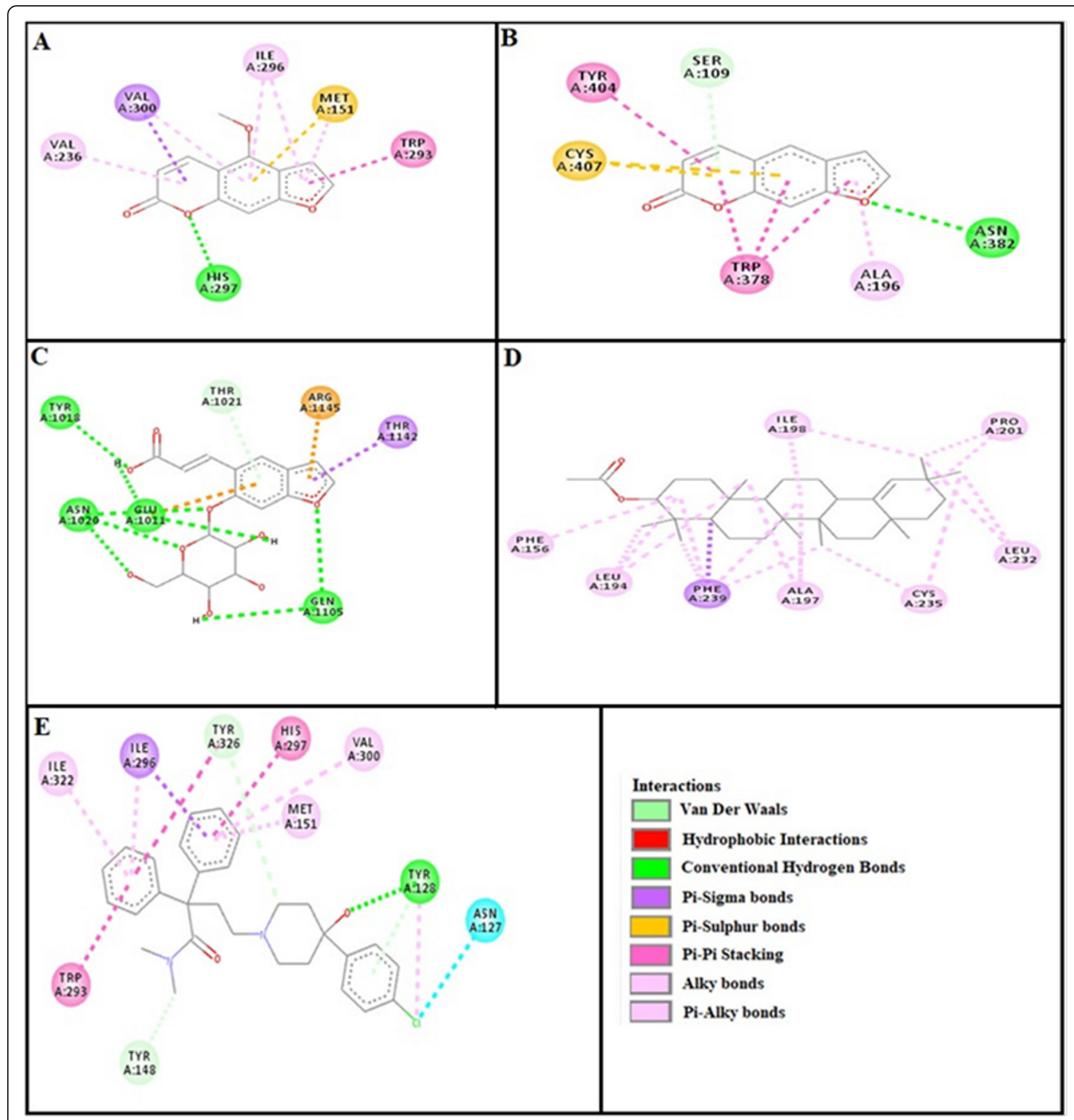

Fig. 15 a, b, c, d and e represents interactions bergapten, psoralene, psoralenoside, germanicol acetate and loperamide against target: mu-opioid receptor respectively, evaluated through Biovia Discovery Studio 2016

germanicol acetate. Ligands having high restricting proclivity shaped interacts with TYR 272 and VAL 270.

\section{Conclusions}

Ficus palmata exhibited anti-diarrheal, anti-secretary, anti-spasmodic, anti-motility and anti-ulcer effects. The plant constituents: psoralenoside and bergapten showed high binding affinities (E-value $\geq-6.5 \mathrm{Kcal} /$ mol) against histaminergic $\mathrm{H}_{1}$, calmodulin and voltage gated L-type calcium channels, while showed moderate affinities (E-value $\geq 7 \mathrm{Kcal} / \mathrm{mol}$ ) against dopaminergic $D_{2}$, adrenergic $\alpha_{1}$, muscarinic $M_{3}$, mu-opioid, whereas revealed lower affinities (E-value $\geq 9.5 \mathrm{Kcal} /$ mol) vs. muscarinic $\mathrm{M}_{1}$, histaminergic $\mathrm{H}_{2}$ and $\mathrm{H}^{+} / \mathrm{K}^{+}$ ATPase pump. Germanicol acetate and psoralene exhibited weak affinities against aforementioned targets. 


\section{Abbreviations}

ACh: acetylcholine; ALA: alanine; ARG: arginine; ASN: asparagine; ASP: aspartic acid; cm: centimeter; $\mathrm{CO}_{2}$ : carbon dioxide; CYS: cysteine; Fp.Cr: Ficus palmata Crude; g: gram; GLN: glutamine; GLU: glutamic acid; GLY: glycine; HIS: histidine; ILE: isoleucine; $\mathrm{K}^{+}$: Potassium; kg: kilogram; LYS: Iysine; MET: methionine; mg: milligram; $\mathrm{mL}$ : mililitre; $\mathrm{O}_{2}$ : oxygen; p.o.: per oral; PHE: phenylalanine; PRO: proline; SER: serine; THR: threonine; TRP: tryptophan; TYR: tyrosine; USc: ulcer surface area of control; USt: ulcer surface area of test drug group; VAL: valine

\section{Acknowledgments}

We are thankful to Higher Education Commission for facilitating us in our research work.

\section{Author contributions}

MBR and NGQ carried out the in-vivo experimentations, computational studies, evaluation of results and documentation. AK supervised the research project and drafted the final manuscript. All authors read and approved the final manuscript.

\section{Funding}

There was no such funding provided for research purpose.

\section{Availability of data and materials}

The datasets used and/or analyzed during the current study are available from the corresponding author on reasonable request.

\section{Ethics approval and consent to participate}

This study was approved by Research and Ethics Committee of Riphah Institute of Pharmaceutical Sciences (Ref. no. REC/RIPS/2017/008). However, no consent was needed for this study.

\section{Consent for publication}

All co-authors have consented for the publication of this manuscript.

\section{Competing interests}

The authors declare that the research was conducted in the absence of any commercial or financial relationships that could be construed as a potential conflict of interest.

\section{Received: 14 December 2018 Accepted: 19 November 2019}

Published online: 03 December 2019

\section{References}

1. Dwivedi SN, Dwivedi S, Patel PC. Medicinal plants used by the tribals and rural people of Satna district, Madhya Pradesh for the treatment of gastrointestinal disease and disorders. Nat Prod Res. 2006;5:60-3.

2. Cseke L, Podila G. MADS-box genes in dioecious aspen II: a review of MADSbox genes from trees and their potential in forest biotechnology. 2004.

3. Colegate SM, Molyneux RJ. An introduction and overview. Bioactive Nat Products. 2007;10-8. CRC press.

4. Nascimento GG, Locatelli J, Freitas PC, Silva GL. Antibacterial activity of plant extracts and phytochemicals on antibiotic-resistant bacteria. Braz Microbiol. 2000;31:247-56.

5. Harrison RD. Figs and the diversity of tropical rainforests. AIBS Bull. 2005;55: 1053-64.

6. Hutchinson J, Dalziel JM. Flora of west tropical Africa, Vol 1, crown agents for oversea governments and administrations. London: Millbank; 1958

7. Kitajima J, Kimizuka K, Tanaka Y. New dammarane-type acetylated triterpenoids and their related compounds of Ficus pumila fruit. Chem Pharm bull. 1999:47:1138-40

8. Abdel-Hameed ESS. Total phenolic contents and free radical scavenging activity of certain Egyptian Ficus species leaf samples. Food Chem. 2009;114: $1271-7$.

9. Alqasoumi SI, Basudan OA, Al-Rehaily AJ, Abdel-Kader MS. Phytochemical and pharmacological study of Ficus palmata growing in Saudi Arabia. Saudi Pharma J. 2014:22:460-71.

10. Li Y-C, Kuo Y-H. Four new compounds, ficusal, ficusesquilignan A, B, and ficusolide diacetate from the heartwood of Ficus microcarpa. Chem Pharma Bull. 2000;48:1862-5

11. Basudan OA, llyas M, Parveen M, Muhisen HM, Kumar R. A new chromone from Ficus lyrata. J Asian Nat Prod Res. 2005;7:81-5.
12. Care A, Committee U. Guidelines for the capture, handling, and care of mammals as approved by the American Society of Mammalogists. J Mammal. 1998:1416-31.

13. Umer S, Tekewe A, Kebede N. Antidiarrhoeal and antimicrobial activity of Calpurnia aurea leaf extract. BMC Complement Altern Med. 2013;13:21-4.

14. Teke GN, Kuiate JR, Ngouateu OB, Gatsing D. Antidiarrhoeal and antimicrobial activities of Emilia coccinea (Sims) G. Don extracts J Ethnopharmacol. 2007;112:278-83.

15. Mehmood MH, Munir S, Khalid UA, Asrar M, Gilani AH. Antidiarrhoeal, antisecretory and antispasmodic activities of Matricaria chamomilla are mediated predominantly through $\mathrm{K}^{+}$-channels activation. BMC Complement Altern Med. 2015;15:75.

16. Ateufack G, Mokam ECD, Mbiantcha M, Feudjio RBD, David N, Kamanyi A. Gastroprotective and ulcer healing effects of piptadeniastrum Africanum on experimentally induced gastric ulcers in rats. BMC Complement Altern Med. 2015;15:214.

17. Ali B, Bashir A. The effect of some $a_{2}$-adrenoceptor agonists and antagonists on gastrointestinal transit in mice: influence of morphine, castor oil and glucose. Clin Exp Pharmacol Physiol. 1993;20:1-6

18. Duhovny D, Nussinov R, Wolfson HJ. 2002. Efficient unbound docking of rigid molecules. Paper presented at the International workshop on algorithms in bioinformatics.

19. Capasso F, Mascolo N, Izzo AA, Gaginella TS. Dissociation of castor oilinduced diarrhoea and intestinal mucosal injury in rat: effect of NG-nitro-Larginine methyl ester. Br J Pharmacol. 1994;113:1127-30.

20. Khan M, Khan A, Rehman N, Gilani AH. Pharmacological basis for medicinal use of Lens culinaris in gastrointestinal and respiratory disorders. Phytother Res. 2014;28:1349-58.

21. Izzo AA, Mascolo N, Capasso R, Germanò MP, De Pasquale R, Capasso F. Inhibitory effect of cannabinoid agonists on gastric emptying in the rat. Naunyn Schmiedeberg's Arch Pharmacol. 1999;360:221-3.

22. Nwinyi F, Binda L, Ajoku G, Aniagu S, Enwerem N, Orisandipe A, Kubmarawa D, Gamaniel KS. Evaluation of the aqueous extract of Boswellia dalzielii stem bark for antimicrobial activities and gastrointestinal effects. Afr J Biotechnol. 2004;3:284-8.

23. Pietta PG. Flavonoids in medicinal plants. In: Rice-Evans CA, Packer L, editors. Flavonoids in health and disease. New York: Dekker; 1998. p. 61-110.

24. Bajorath J. Integration of virtual and high-throughput screening. Nat Rev Drug Discov. 2002;1:882.

25. Zhong Z, Liu LJ, Dong ZQ, Lu L, Wang M, Leung CH, Ma DL, Wang Y. Structure-based discovery of an immunomodulatory inhibitor of TLR1-TLR2 heterodimerization from a natural product-like database. Chem Commun. 2015:51:11178-81

26. Dallakyan S, Olson AJ. Small-molecule library screening by docking with PyRx Chem biology. Springer. 2015:243-50.

27. Guo F, Li SC, Wang L, Zhu D. Protein-protein binding site identification by enumerating the configurations. BMC Bioinform. 2012:13:158.

28. Patil R, Das S, Stanley A, Yadav L, Sudhakar A, Varma AK. Optimized hydrophobic interactions and hydrogen bonding at the target-ligand interface leads the pathways of drug-designing. PLoS One. 2010;5:12029.

\section{Publisher's Note}

Springer Nature remains neutral with regard to jurisdictional claims in published maps and institutional affiliations.

Ready to submit your research? Choose BMC and benefit from:

- fast, convenient online submission

- thorough peer review by experienced researchers in your field

- rapid publication on acceptance

- support for research data, including large and complex data types

- gold Open Access which fosters wider collaboration and increased citations

- maximum visibility for your research: over $100 \mathrm{M}$ website views per year

At BMC, research is always in progress.

Learn more biomedcentral.com/submission 